\title{
Confronting Scales of Settlement Hierarchy in State-Level Societies: Upper Mesopotamia and Central Anatolia in the Middle Bronze Age
}

\author{
Alessio Palmisano \\ Institute of Archaeology \\ University College London
}

\begin{abstract}
In this article, I adopt a long-established method known as rank-size analysis to detect particular settlement patterns in the Khabur Triangle (KT) and central Anatolia (CA) during the Middle Bronze Age. Archaeologists must be particularly careful when applying rank-size analysis to a given study area as the results can change at a different spatial scale. With these premises in mind, in this work, I first show the results produced by performing rank-size analyses on the two whole study areas and assess comparatively any difference in the observed patterns between them. Second, I break down each study area into smaller window analyses in order to detect how settlement size distributions change at a more local scale. The results show that at a larger regional scale, both central Anatolia and the Khabur Triangle in the Middle Bronze Age are characterized by fragmented politically landscapes of competing independent polities loosely integrated. By contrast, at smaller local scales central Anatolia and the Khabur Triangle show a different picture. In central Anatolia settlement systems appear more nucleated in large centres dominating their surrounding rural hinterlands and strong political and economic centralization is evident at Kültepe and Boğazköy. On the other hand, in the Khabur Triangle settlement primacy is less accentuated and the polities are more loosely integrated. These examples demonstrate the advantage of using rank size analysis at different spatial scales for having a complete understanding of the dynamics behind the observed empirical data.
\end{abstract}

Keywords: Rank-size analysis, cluster analysis, settlement hierarchy, city-states, urban systems, Near East, Middle Bronze Age, Upper Mesopotamia, Central Anatolia

\section{Introduction}

Identifying regional settlement hierarchy by using site size has been a common practice among geographers, economists and archaeologists in the past decades (Zipf 1949; Crumley 1976; Dziewonski 1972; Kowalewski 1990; Krugman 1991a-b; Roberts 1996; Pumain and Moriconi 1997; McAndrews et al. 1997; Brakman et al. 1999; Blank and Salomon 2000; Clauset et al. 2009; Berry and Okulicz-Kozaryn 2012; Cristelli et al. 2012; Jiang et al. 2015). In particular, urban primacy (or nucleation), in the form of an excessive concentration of population in a few central cities, and dispersion as a population evenly distributed across settlements of equal size represent the extreme patterns among a wide range of possible site size structures (see Jones 2010; Peterson and Drennan 2011; Crema 2013; Duffy 2015; Altaweel et al. 2015). In this perspective, the ranksize graph has been used in archaeology for over 40 years for studying population distributions and regional settlement patterns (e.g. Johnson 1972, 1977 and 1980; Blanton 1976; Crumley 1976; Pearson 1980; Adams 1981; Kowalewski 1982; Paynter 1982; Falconer and Savage 1995; Savage 1997; Fall et al.1998; Savage and Falconer 2003; Drennan and Peterson 2004 and 2008; Wossink 2009, 89-91; Marzano 2011; Crema 2013 and 2014, Duffy 2015; Smith 2015, 326-328). Many scholars have legitimately criticised a linear relationship between site size and settlement hierarchy in middle-range and stateless societies (see Crumley 1979; Kantner and Kintigh 2006; Peterson and 
Drennan 2011; Duffy 2015) and emphasized how settlement size distributions can be the product of other factors such as climate events (Habu 2001; Chatters and Prentiss 2005), subsistence strategies (Vita Finzi and Higgs 1970; Flannery 1976; Kohler 2004; Ullah 2011; Crema 2013 and 2014), seasonal occupation (Flannery 1976; Price and Brown 1985; Kelly 1992), group fission (Forge 1972; Johnson 1982; Crema 2013) and functional specialization (Renfrew 1974; Renfrew and Level 1979; Pearson et al. 2006). However, when dealing with state-level societies, characterized by territorial compactness and a capital city or town economically and politically integrated with its immediately surrounding rural hinterland, an association between site size hierarchy and political centralization is still valid (see Wright 1978 and 1986; Hinsley 1986, 22-26; Trigger 1993, 8-14; Charlton and Nichols 1997; Fall et al. 1998, 111-112; Hansen 2000 and 2002; Savage and Falconer 2003; Smith 2003, 149-183; Ur 2013; Altaweel et al. 2015; Palmisano and Altaweel 2015a).

Bearing in mind the above issues, in this article I investigate in a comparative perspective, which different dynamics produced past human settlement hierarchy in the Khabur Triangle (KT) and in Central Anatolia (CA) during the Middle Bronze Age (ca. 2000-1600 BC; MBA). In this period, the distribution of settlement sizes in these regions was relatively broad, with numerous small and medium sized sites and only a few large sites. This settlement structure arguably reflects the actual political landscape in the early second millennium, which was fragmented into several independent city-states (for CA see Veenhof and Eidem 2008, 147-179; Barjamovic 2011, 6; Barjamovic et al. 2012, 48-50; Palmisano 2014; Palmisano and Altaweel 2015a and 2015b; for the KT see Charpin and Ziegler 2003; Veenhof and Eidem 2008, 290-321; Ristvet 2008 and 2012; Palmisano 2015; Palmisano and Altaweel 2015a and 2015b; Altaweel et al. 2015). Hence, I use in combination two long-established methods such as rank-size and $k$-means analyses to respectively assess settlement size structures and identify spatial clusters of settlements as an approximation of spatially defined political units. I will use a multi-scalar approach to detect specific spatial and functional patterns on both local and regional scales and to tackle possible misunderstandings derived from analysing data just on a single scale of analysis (see discussion in Daly and Lock 2004; Mathieu and Scott 2004; Lock and Molyneaux 2006). Scholars have pointed out how different scales of approach may produce different results and mask significant spatial variations detectable only at a specific scale of analyses (Bird 1989, 22; Goodchild and Quattrocchi 1996, 5; Harris 2006, 48-50). In particular, Drennan and Peterson (2004, 535-539) have emphasized this problem by comparing the results of rank-size analyses obtained with sample blocks of four different sizes. More recently, Cristelli et al. (2012) advocated a broader use of multi-scalar approaches since economic and political integrated settlement systems are discernible only at a given geographical scale (e.g. the national state in the modern European Union).

I firstly begin with a review of state-level societies and in particular of city-states. I then provide background about the two case studies in the section below. Then, I introduce and explain the ranksize and $k$-means methods and the advantages of multi-scalar modelling approaches. Subsequently, the modelling results, including outputs from the two different methods used, are provided. Finally, conclusions are drawn with regard to the methodology and its potential for understanding the development of settlement hierarchies.

\section{Background}

\subsection{Defining cities, states and city-states}

Archeologists, sociologists, anthropologists, and historians have attempted to classify states according to a wide range of different criteria. Some scholars have focused on the administrative and bureaucratic apparatus, framing the state within either a simpler or more elaborated structure (Weber 1978, 1028-1031), or they have offered a more complex taxonomy based on the development of social and hierarchical ties among different political agents (Claessen and Skalník 
1978, 22-23; Crumley 1995). Other scholars have preferred to emphasise a close relationship between early urbanism and complex forms of social organization and how the economic and political centralization of the state manifests itself in the form of nucleated settlements (see Fox 1977; Ades and Glaeser 1995). Fox pointed out that the administrative and centralized structure of the state is an extension of the bureaucratic city, due to its capability to extract sources and labour from the surrounding rural hinterland (1977, 34-37). On the other hand, Trigger separates the discussion between urban and state formation by asserting that states can exist without cities, but not vice-versa $(1972,576)$. Trigger is even more categorical by recognizing only two kinds of states: city-states and territorial states. The first one indicates an urban centre and its hinterland, while the latter one was a larger entity with multiple administrative centres ruled by residents linked to the state (Trigger 2003, 266-267). Nevertheless, Hansen $(2000,16)$ objects to this dichotomy and says that a city-state is merely a territorial state with a small territory and well-defined borders. In addition, he suggests that it is more appropriate to replace the misleading term "territorial state" with "macro-state" to denote those "states in possession of a large territory dotted with urban centres, of which one is capital" $(2000,16)$. Hence, the city-state is one of the most common forms of micro-state. Slightly different is the position of Marcus $(1998,92)$, who argues that territorial and city-states "were often different stages in the dynamic cycles of the same states, rather than two contrasting socio-political types," and that the clusters of city-states in a specific area was the result of the political collapse of earlier unitary states.

Our understanding of city-states as socio-political unit has been significantly enhanced by the massive comparative study of thirty-six city-state cultures promoted by Hansen (cf. Hansen 2000 and 2002). Hansen deliberately draws an idealised picture (2000, 17-19), in which a city-state is a highly institutionalized and centralized political unit characterized by one capital city or town that is well-integrated socially with its surrounding hinterland and inhabited by a stratified population in which there are citizens, foreigners, and slaves. Within the city-state territory there could have been other nucleated settlements apart from the major urban centre, but in such cases, they are secondorder settlements (Fig.1). The territory is also sufficiently small that its boundary can be reached in a day's walk out or less ${ }^{1}$, and hence the number of people acting as privileged political actors is also small ${ }^{2}$. Hansen $(2000,15)$ argues that the population of a city-state may share an ethnic identity with the population of neighbouring city-states, as its sense of political identity is primarily embodied via the city itself and differentiated from other city-states (see also Emberling and Yoffee 1999). On the other hand, some scholars have conceived the city-state as ethnically distinct from other neighbouring city-states (cf. Burke 1986; Marcus 1989, 201; Trigger 1993, 8-14; Charlton and Nichols 1997, 1).

Numerous pieces of archaeological evidence suggest that urban centres did not have enough land to sustain their population, and thus they relied upon food surplus produced by rural communities dispersed around the cities (Wattenmaker 2009, 116).

The city-state is not necessarily independent and can be tributary polity or domain of another citystate, or of a territorial state (Hansen 2000). Perhaps boundaries between city-states were continuously contested and centres competed with one other in order to guarantee the control of natural resources, with particular geographical features having a strategic military role (e.g. mountain passes, commanding views over landscape from the top of hills, fords, etc.), and grazing lands (Yoffee 2004, 56). Both settlement patterns and texts reveal that the city-states were often part of a "peer-polity system," a world of politically independent but economically and socially interdependent and roughly equivalent polities (Renfrew 1986, 1; Wattenmaker 2009, 118,123).

\footnotetext{
${ }^{1}$ The ideal maximum extent of the surrounding hinterland has been defined by Hansen of around $30 \mathrm{~km}$ and, generally, the size of a city-state ranges between 10 and 3,000 square kilometers $(2000,17)$.

${ }^{2}$ A city state has usually a population of several thousands of inhabitants (Hansen 2000, 601). Nevertheless, very small city-states can also have a population lower than one thousand inhabitants (Di Cosmo 2000, 397), while over-sized city-states may reach 100,000 number of inhabitants (Hansen 2000, 18; Yoffee 2004, 62).
} 
The success of the larger territorial states depended on the ability of the new rulers to coerce and co-opt the urban elites of the former city-states within the structural and political texture of their regional kingdoms (Roth 1997, 76-81; Garfinkle 2013, 116). Those elites, in fact, were at the centre of the ideological and redistributive networks of the cities, as administrative, religious and military officers. The study of the available archaeological end textual evidence has revealed that the political landscapes of western Asia probably witnessed a series of repeated cycles from small political entities to large territorial states over the course of the period from the fourth to the first millennium BC (Marcus 1998; Strange 2000; Thuesen 2000; Hansen 2002, 13; Yoffee 2004, 131160; Ur 2010a, 404-414; Ur 2013, 148-152). During this period, city-states remained the more stable and longest-lasting political unit, while the larger regional kingdoms were often politically fragile and could last only one a generation or a single dynasty (Garfinkle 2013). At this point, "one can present a model of Mesopotamian history in terms of a pendulum swinging between periods of political fragmentation and central rule" (Barjamovic 2013, 123). At times, the region was divided into hundreds of city-states and tribal communities, and at other times a large and centralized state imposed its authority upon numerous and weaker existing political entities. The political centre of a larger territorial state may have been a former city-state that rose to supremacy (see Carneiro 1970 and 1981; Turchin et al. 2013; Altaweel et al. 2015).

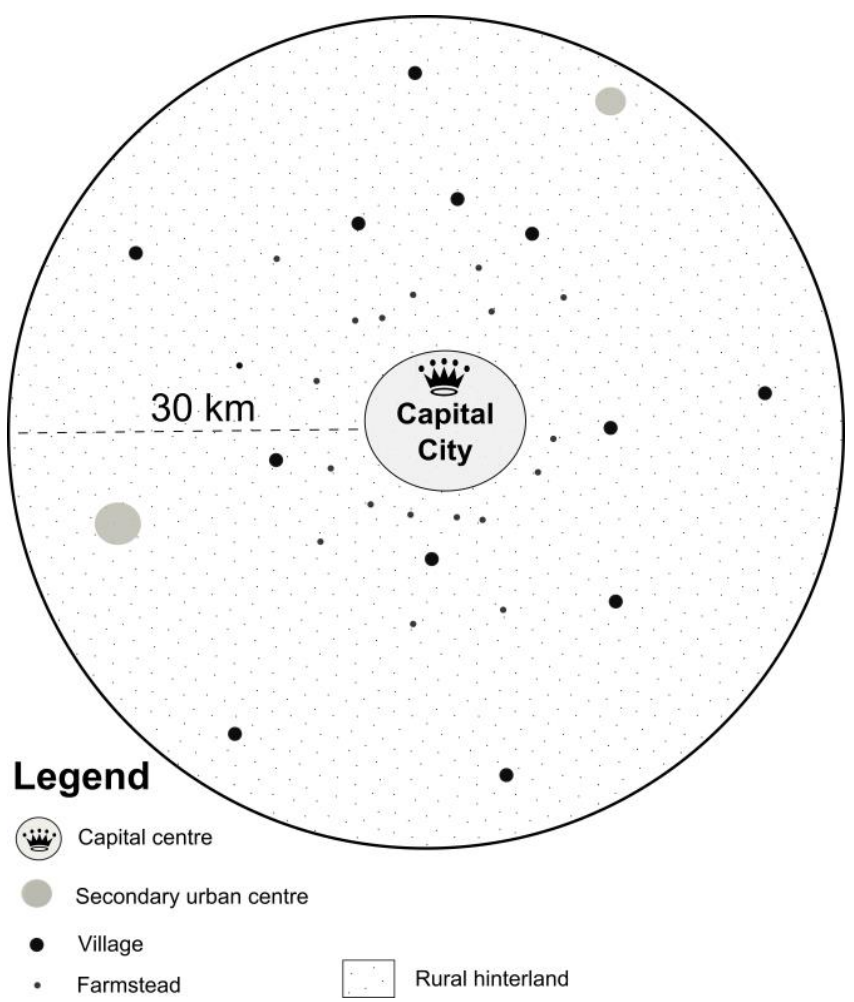

Figure 1. A schematic, highly stylised model of city-state (based on Hansen 2000).

\subsection{Case studies and historical background}

For the purpose of this project, two different well-defined regions have been chosen. The first case study is the KT (Fig. 2a), an area located within the Syrian Jazira, measuring some $16,500 \mathrm{~km}^{2}$ and extending between the Tigris and Euphrates Rivers, bounded by what is today the Syrian/Iraqi border to the east, the Syrian and Turkish border to the north, the Jebel Sinjar and by the Jebel 'Abd-al-Aziz to the south and the Khabur River to the west. The second case study is CA (Fig. 2b), a region covering a total area of about $71,000 \mathrm{~km}^{2}$ between the Pontic Mountains to the north and the Taurus mountains to the south. The choice of the two regions has been influenced (1) by the 
limited number of regions where a sufficiently high intensity of archaeological excavations and surveys has been conducted, and (2) by the need to provide a coherent framework for analysing settlement systems in two regions characterized by a similar patchwork of numerous small citystates during the MBA and two different geographical settings, an open tableland in the KT versus a mountainous inland area with large intermountain river valleys in CA.

The surviving cuneiform corpus from Upper Mesopotamia has yielded few textual clues for the first two centuries of the second millennium BC. On the other hand, the scantiness of written sources from the first two centuries of the second millennium BC ( $c a .2000-1800 \mathrm{BC}$ ) contrasts with its richness in the 18th century BC. In fact, the archives from Tell Leilan, Tell al-Rimah, Mari, Tell Šemšara and Chagar Bazar have provided a large amount of data for reconstructing the political and economic geography of Northern Mesopotamia in the 18th century BC. Tell Leilan's Eastern Lower Town Palace archive has yielded 600 clay tablets (e.g. administrative texts, letters, and political treaties) retrieved during the archaeological excavations carried out in 1985 and in 1987 (see Eidem 2010). These documents are important for reconstructing the history of Šubat-Enlil/Šehna during the period of its last three kings Mutiya, Till-abnû and Yakūn-Ashar (ca. 1750-1728). Mari has yielded a huge amount of written sources ( $c a$. 22,000 clay tablets) that have allowed scholars to reconstruct the political geography in the Middle Euphrates and in Northern Mesopotamia during the period of Yashmakh-Addu and Zimri-Lim's kingdoms ( $c a .1800-1758$ BC). Other texts come from Tell Šemšara (146), Tell al-Rimah (269), Tell Taya (2), Chagar Bazar (218), Tell Ashara (ca. 550), and Tell Bi'a (ca. 380). From the available textual evidence, it seems that the Khabur Triangle was fragmented into several city-states in the first two centuries of the second millennium BC (2000-1800 BC). Tell Leilan was not occupied during the Leilan Period IIc (ca. 2200-1900 BC). In the late $19^{\text {th }}$ century BC and in the first half of the $18^{\text {th }}$ century BC the Khabur Triangle was under the control of several short-lived regional states able to conquer large territories as a consequence of military successes. Šamši-Adad conquered Aššur in 1808 and then extended his dominion westward to Tuttul on the Balikh River, and he founded a new royal capital at Šubat-Enlil, modern Tell Leilan (Villard 1995, 873; Charpin and Ziegler 2003; Van de Mieroop 2007, 107). In order to control a so large kingdom Šamši-Adad I (1808 - 1776 BC) put his sons on the throne at two strategic locations. The eldest, Išme-Dagan (1775-1761? BC), was appointed king of Ekallatum, a kingdom stretching from the Zagros mountains to the Tigris River, while the younger Yasmakh-Addu became king of Mari. After Šamši-Adad I's death, Yasmakh-Addu was defeated by the king of Yamkhad YarimLim, who helped Zimri-Lim (1780 - 1758 BC) to become the new king of Mari and establish his power over the northern Jazira. In the second half of the $18^{\text {th }}$ century the Khabur Triangle once again became a patchwork of several small city-states characterized by fluid and ambiguous borders (Eidem 2000 and 2008; Ristvet 2008).

In central Anatolia, most written sources (c. 22,500 clay tablets) come from the archaeological site of Kültepe and a little more than one hundred from other sites in central Turkey such as Bögazköy (72 texts), Alişar Höyük (63), Kaman Kalehöyük (2), and Kayalıpınar (1; see Michel 2003, 2006 and 2011). The textual evidence reveal that central Anatolia was balkanised into several independent city-states distributed in five different zones (Barjamovic 2011): the Middle Euphrates (Nehria, Batna, Zalpa, Uršu, Hahhum, Mamma); the territory within the Kizılırmak basin (Kaneš, Amkuwa, Samuha); Konya plain (Purušhaddum, Ulama, Wahšušana, Šalatuwar); the Halys region (Hattuš, Karahna, Durhumit) and the Pontus (Zalpuwa). In the 18th century, some sizeable territorial states made their first appearance in central Anatolia. Kaneš (Kültepe) imposed its power over Amkuwa, Lakimišša, Salahšuwa and Taišama (Barjamovic et al. 2012, 49-50). Then, the king of Kuššara Pithana, a city likely located to the southeast of Kizilirmak basin, conquered Neša (Kaneš) and captured its king Waršama (Hamblin 2006, 293). After his death, Pithana's son and successor Anitta extended his kingdom over the southern half of Central Anatolia (Barjamovic et al. 2012, 50). However, Anitta's power was not long to last, and a successful revolt of vassal cities resulted in the destruction of the city of Neša and in Anitta's empire fall (c. $1725 \mathrm{BC}$ ). The political 
landscape of Central Anatolia returned instable and fragmented, and in this new situation Zuzu, king of Alahzina, conquered Kaneš and took himself the title of Great King.

\subsection{Archaeological data}

Archaeological excavations and surface surveys carried out across the KT and CA provide the bulk of data about the spatial location and extent of settlement at both regional and local scales, as well

as about settlement occupation histories. Nevertheless, the actual available data can be problematic; site densities from surveys carried out in CA are far lower (ranges from 0.4 to 5 sites per $100 \mathrm{~km}^{2}$ ) than those recorded in systematic and extensive regional surveys performed in the KT (around 10 or more sites per 100 km²; e.g., Ristvet, 2005; Wright et al., 2006-2007; Ur and Wilkinson, 2008; Ur 2010b) and just a few have been intensively carried out in Paphlagonia (Matthews and Glatz, 2009), in Gordion (Kealhofer, 2005), in the Lower Euphrates basin (Özdoğan, 1977), and around Boğazköy (see Fig. 2a-b and Table 1 for a list of surveys carried out in the KT and CA). In addition, existing publications indicate only the overall extent of mounds but neither the size for a particular chronological phase nor the extent of the surrounding lower town. Therefore, we can provide only very rough estimates of the empirical extent of MBA sites in the KT and CA, and any results derived from the analyses of the archaeological surveys' data have to be interpreted cautiously, as constituting evidence only about the patterns exhibited by relatively large, sedentary farming communities. Nevertheless, the larger and smaller mounds do likely present themselves as relative proxies for sites that were possibly greater or smaller than surrounding settlements.

In addition, without the support of stratigraphic data from excavations, sites' occupation periods can be only established on the basis of the chronological resolution of a given pottery type. For example, in the Khabur Triangle, surveyed sites have been commonly dated to the Middle Bronze Age (ca. 2000-1600 BC) by using Khabur Ware as a chronological marker. The problem with this diagnostic pottery is that, on the basis of small potsherds collected from surface, the "Early" (phases 1-2: ca. 2000-1750/30 BC) and "Late" (phases 3-4: ca. 1750/30-1400 BC; see Oguchi 2006 for this periodization) versions of Khabur Ware are difficult to distinguish archaeologically. In north/central Anatolia the conservative aspect of the pottery assemblage of second millennium BC makes any dating from surface collection possible in only very broad terms and divide the second millennium into early, middle and late phases (cf. Schoop 2003, 2006 and 2009; Glatz et al. 2009, 108-110). The early phase comprises broadly the Old Assyrian Colony period or Middle Bronze Age (ca. 2000$1600 \mathrm{BC}$ ). Hence, when we analyse the sites dated on the basis of these long-living pottery types, we should take into account that the available picture under the assumption that sites dated to the same archaeological phase are contemporaneous is biased.

In the KT, relevant survey data include: Meijer (1986), Eidem and Warburton (1996), Lyonnet (2000), Ristvet (2005), Wright et al. (2006-2007), Ur and Wilkinson (2008), and Ur (2010b; see Fig. 2a and Table 1). Other nearby surveys (Algaze 1989; Wilkinson and Tucker 1995; Ball 2003) have been left out of the analysis, as these are not as continuous as the others. Within the KT, 439 were occupied in the MBA (Fig. 2a). In the eastern KT, the Tell Leilan survey's area alone has 157 sites during the MBA (Ristvet 2005). Here, the dominant role of Tell Leilan is clear, which had an area of ca. 90 ha with many surrounding small villages. Other major centres include Tell Farfara (ca. 70 ha) and Tell Muhammed Diyab (ca. 35 ha). Along the Wadi Jaghjagh, the main settlements were Tell Brak (ca. 20 ha) and Tell Barri (ca. 9 ha).

Within CA, 440 sites were occupied during the MBA (Fig. 2b and Table 1). Other nearby archaeological surveys have been left out of the analysis because these are not as continuous with the others and there are gaps in the archaeological dataset. The settlement system in the Anatolian central plateau is characterized by few large sites such as Kültepe (ca. 50 ha), Acemhöyük (ca. 55 ha), Bögazköy (ca. 25 ha), Yassihöyük (ca. 25 ha), Varavan Höyük (ca. 25 ha), and Alişar Höyük (ca. 20 ha), with many surrounding small settlements. 
In the Khabur Triangle the extremely favourable conditions of site visibility and obtrusiveness allow archaeologists to reach acceptable levels of intensity by making use of remote sensing data (e.g. CORONA, ASTER satellite imagery) without necessarily adopting pedestrian transects (Ur 2010b, 40-41). In this perspective, a combined spectral-spatial analysis of satellite images (ASTER, CORONA, SPOT) and elevation models (SRTM) has allowed the researchers to map the anthropogenic soils and identify around 15,000 sites in the Khabur Triangle (see Menze et al. 2007; Menze and Ur 2012a-b and 2013). A simple visual inspection of the anthropogenic soils detected shows that there is not a significant difference in settlement density between the western and eastern $\mathrm{KT}^{3}$.

On the contrary, archaeological survey data provide a different picture: the eastern Khabur Triangle shows higher site density than the western Khabur Triangle. This aspect could be a reflection of ancient settlement strategies, but it is most likely biased by the intensity of the archaeological surveys carried out in the area. In fact, just two archaeological surveys have been carried out in the western Khabur Triangle (Lyonnet 2000; Ur and Wilkinson 2008) and they strongly differ in terms of site density (18.28 sites x 100 sq. km of Ur and Wilkinson 2008 versus 3.15 sites x $100 \mathrm{sq}$. km of Lyonnet 2000; see Table 1). Most of the western Khabur Triangle has, therefore, been surveyed extensively and low-intensively by Lyonnet (2000) and shows a lower site density if compared with the eastern side more intensively surveyed (see site density of the surveys no. 3-5 in the Table 1). Hence, the overall picture of the Khabur Triangle, in terms of site density, is perhaps distorted by the different methodologies of the archaeological surveys carried out. On the other hand, what is undoubtedly evident is that in the eastern Khabur Triangle there are larger settlements than in its western part during the Middle Bronze Age.

In central Anatolia, a lower site visibility and obtrusiveness, when compared with the Khabur Triangle situation, perhaps should have made the adoption of walking transects a necessity. Instead, the vast majority of archaeological surveys carried out in central Anatolia fall within the "extensive" category and we have just a few examples of regional investigations undertaken by using walking transects (see Matthews and Glatz 2009). In fact, site densities from surveys carried out in central Anatolia (see Figs. 105-107) are far lower (ranges from 0.4 to 5 sites per $100 \mathrm{sq} . \mathrm{km}$.) than those recorded in systematic and extensive regional surveys performed in the Khabur Triangle (around 10 or more sites per 100 sq. km; e.g. Ristvet 2005; Ur and Wilkinson 2008; Ur 2010b) or in other parts of Anatolia (range from 6 to 10 sites per sq. km.; e.g. Boyer et al. 2006; Abay 2011). Topographic variability is another issue to be considered in the Anatolian context. Central Anatolia is characterized by lowland areas, high intermountain valleys and plateaus framed by the Pontic Mountain and the Taurus ranges, which respectively reach up to ca. 3,000 and 3,700 meters above sea level. Mountainous fringes and areas with rugged topography are marginal zones that have not commonly received as detailed archaeological attention as lowland areas for a series of practical reasons such as difficult terrain and dense vegetation cover (see Banning 1996; Wilkinson 2003, 185). In central Anatolia there is just one example of an archaeological survey including higheraltitude landscapes in its investigations (see Matthews and Glatz 2009).

\footnotetext{
${ }^{3}$ See the results in the "Harvard-Heidelberg Atlas of Settlement Patterns at the Upper Khabur River" available online: http://www.habur.org/
} 

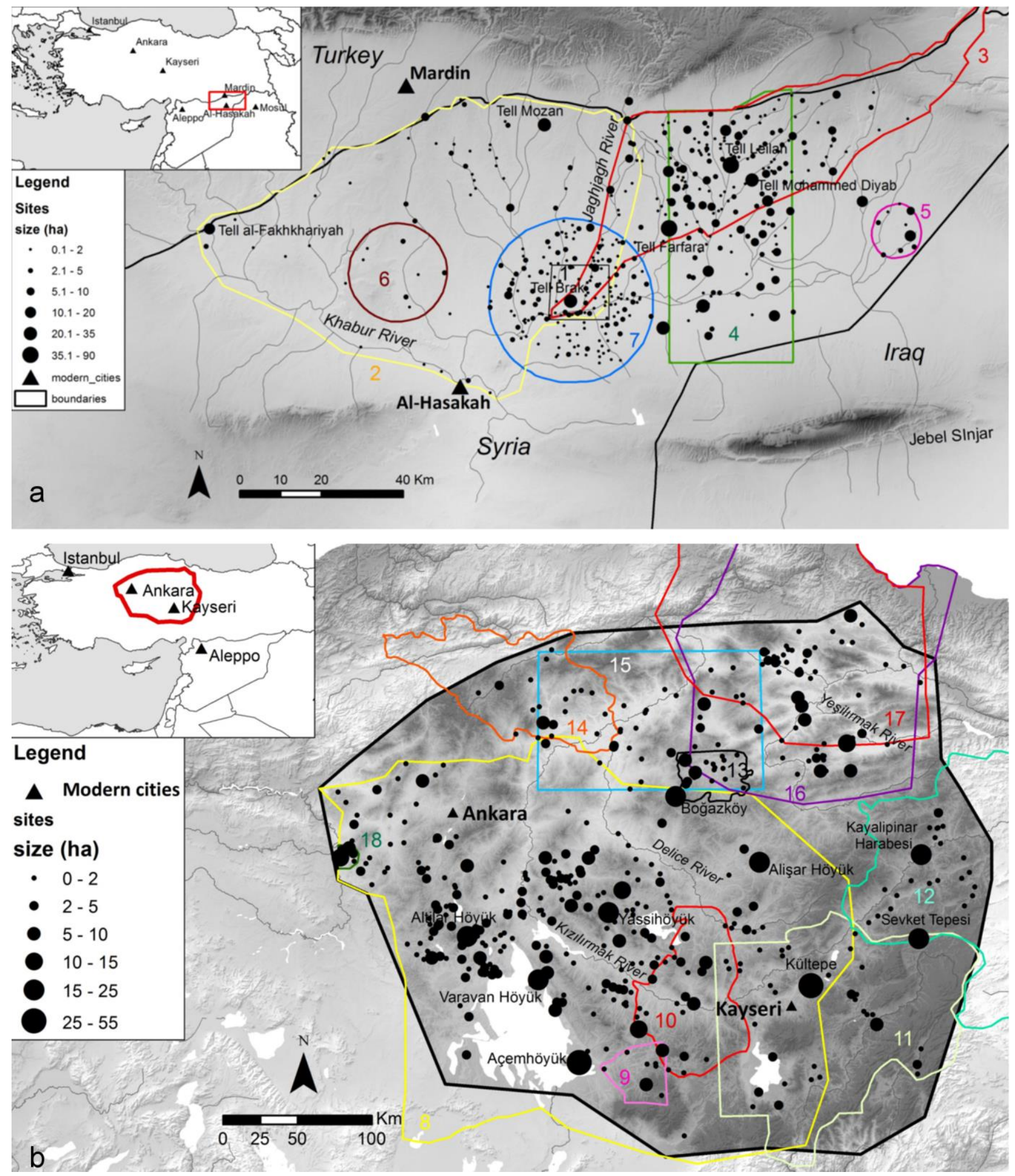

Figure 2. Map showing the case studies and the archaeological surveys carried out in the Khabur Triangle (a) and in central Anatolia (b). 


\begin{tabular}{|c|c|c|c|c|c|c|}
\hline \multicolumn{7}{|c|}{ Khabur Triangle } \\
\hline $\begin{array}{l}\text { Map } \\
\text { no. }\end{array}$ & Season & Reference & $\begin{array}{c}\text { Area } \\
(\mathrm{sq} . \mathrm{km})\end{array}$ & $\begin{array}{c}\text { Total } \\
\text { n. sites }\end{array}$ & $\begin{array}{l}\text { n. MB } \\
\text { sites }\end{array}$ & $\begin{array}{l}\text { Sites density (x } \\
100 \text { sq. } \mathrm{km}) \\
\end{array}$ \\
\hline 1 & 1988 & $\begin{array}{l}\text { Eidem and Warburton } \\
1996\end{array}$ & 193 & 56 & 19 & 29.01 \\
\hline 2 & 1989-1991 & Lyonnet 2000 & 5,100 & 161 & 45 & 3.15 \\
\hline 3 & $\begin{array}{l}1976-77 ; \\
1979\end{array}$ & Meijer 1986 & 2,296 & 290 & 152 & 12.63 \\
\hline 4 & $\begin{array}{l}1984 ; 1987 \\
1995 ; 1997\end{array}$ & Ristvet 2005 & 1,919 & 335 & 157 & 17.45 \\
\hline 5 & 1999-2001 & Ur 2010b & 127 & 60 & 9 & 47.24 \\
\hline 6 & $1997-98$ & Ur and Wilkinson 2008 & 454 & 83 & 7 & 18.28 \\
\hline 7 & $2002-2003$ & Wright et al. 2006-2007 & 1,275 & 268 & 74 & 21.01 \\
\hline \multicolumn{7}{|c|}{ Central Anatolia } \\
\hline \multirow{14}{*}{8} & 1990 & Omura 1992 & 58,847 & 53 & 36 & 0.09 \\
\hline & 1991 & Omura 1993 & 6,899 & 30 & 11 & 0.43 \\
\hline & $1992-93$ & Omura 1994 and 1995 & 4,322 & 102 & 48 & 2.36 \\
\hline & 1994 & Omura 1996a-b & 12,143 & 54 & 25 & 0.44 \\
\hline & 1995 & Omura 1997 & 1,634 & 43 & 12 & 2.75 \\
\hline & 1996 & Omura 1998 & 1,037 & 51 & 8 & 4.91 \\
\hline & $1999-2000$ & Omura 2000 and 2001a & 6,152 & 66 & 18 & 1.07 \\
\hline & 2000 & Omura 2001b & 2,057 & 64 & 18 & 3.11 \\
\hline & 2001 & Omura 2002 & 4,555 & 68 & 33 & 1.49 \\
\hline & 2002 & Omura 2003 & 1,786 & 106 & 10 & 5.95 \\
\hline & 2005 & Omura 2006 & 2,672 & 46 & 13 & 1.72 \\
\hline & 2006 & Omura 2007a & 3,529 & 40 & 13 & 1.13 \\
\hline & $2003-06$ & Omura 2007b & 7,988 & 190 & 56 & 2.39 \\
\hline & 2007 & Omura 2008 & 1,435 & 53 & 20 & 3.69 \\
\hline 9 & 1993 & Gülçur 1995 & 1,341 & 61 & 9 & 4.54 \\
\hline 10 & $1997-98$ & Senyurt 1998 and 1999 & 5,804 & 53 & 16 & 0.91 \\
\hline 11 & $2008-10$ & $\begin{array}{l}\text { Kulakoğlu et al. } 2009 \text { - } \\
2011\end{array}$ & 19,194 & 87 & 43 & 0.45 \\
\hline 12 & $\begin{array}{l}\text { 1992-95, 97- } \\
99 ; 2007\end{array}$ & $\begin{array}{l}\text { Ökse 1994-97, 1999- } \\
\text { 2001; Engin 2009 }\end{array}$ & 27,789 & 476 & 31 & 1.71 \\
\hline 13 & $1988-89$ & Süel 1989 and 1990 & 1,440 & 28 & 9 & 1.94 \\
\hline 14 & $1997-2001$ & $\begin{array}{l}\text { Matthews and Glatz } \\
2009\end{array}$ & 7,737 & 337 & 19 & 4.35 \\
\hline 15 & $\begin{array}{l}\text { 1996-1997, } \\
2002,2006\end{array}$ & $\begin{array}{l}\text { Sipahi and Yildirim } \\
1999-2000,2004,2008\end{array}$ & 13,964 & 66 & 20 & 0.47 \\
\hline 16 & $\begin{array}{l}1989,1995- \\
98,2001-05, \\
2007\end{array}$ & $\begin{array}{l}\text { Özsait 1991,1998-2000, } \\
\text { 2002-07, 2009; Özsait } \\
\text { and Özsait } 2001\end{array}$ & 26,454 & 411 & 26 & 1.55 \\
\hline 17 & $1997-99$ & $\begin{array}{l}\text { Dönmez 1999-2000, } \\
2002\end{array}$ & 23,408 & 85 & 32 & 0.36 \\
\hline 18 & 1996-2002 & Kealhofer 2005 & 200 & 25 & 9 & 12.5 \\
\hline
\end{tabular}

Table 1. List of archaeological surveys carried out in the Khabur Triangle and central Anatolia.

\section{Methods}

\subsection{Rank-size analysis}

The "rank-size" rule was originally presented by Auerbach (1913), who observed that "the cities of modern industrial nations, when ranked according to their population, are distributed such that the largest city is twice the population of the second-ranked city, three times the population of the thirdranked city and so on". According to this rule, in a given settlement system the size of the $n$ thranked site is predicted by dividing the size of the largest settlement by its own rank. Therefore, in a settlement system whose largest site is 12 ha, the rank 2 settlement would be 6 ha, the rank 3 settlement 4 ha, and so on. Zipf (1949) theorised that the rank-size relationship was the result of two different forces: a "Force of Unification," which encourages settlement aggregation and a "Force of Diversification," which defines settlement dispersion. When they are in balance, the various 
settlements conform to the rank-size rule (Savage 1997, 233). Zipf (1949) expressed this rule with the following formula:

$P=K x r^{-q}$

where the size of a given observation $(P)$ can be predicted if its rank $r$, the size of the largest observation $(K)$, and the constant $q$ are known. When $q$ is greater than 1 , we have settlement systems characterised by a few large dominant centres, while when $q$ is lower than 1 , the settlement system is less integrated and a more uniform distribution of sizes can be observed. Instead, when these forces of unification and diversification are in equilibrium, $q$ will be equal to 1 , and we will have a so-called 'Zipf's Law'of settlement size distribution. For graphical simplicity, rank-size graphs are usually plotted on a log-log scale, so that expected rank-size rule (Zipf's Law) results in a straight line from the upper left to the lower right corner of the plot (Fig. 3a).

In archaeology, the distributions of settlement size often do not conform to the rank-size rule and plotted settlement size distributions can be steeper (primate distribution, Fig. 3b) or shallower (convex distribution, Fig. 3c) than the Zipf's Law (Fig. 3a). However, these deviations from the expected rank-size rule usually do not follow a straight-line, and in some cases the force of unification and diversification act at different rank levels, resulting in a mixed and non-linear relationship between rank and size. Hence, researchers have also introduced the idea of primoconvex distributions when respectively at higher and lower ranks a primate and convex pattern are evident (Fig. 3e) or even double-convex distributions when two convex patterns are evident at different rank levels (see Fig. 3d; Falconer and Savage 1995, 39-41; Savage 1997, 234).

A wide range of explanations has been proposed for interpreting those types of rank-size distribution that differ from Zipf's Law (for a summary of the explanations provided for various rank-size outcomes see Savage 1997, table 1). Primate distributions imply that in a settlement system there are one or only a very few large centres and a higher number of smaller settlements. This could indicate strong vertical integration and extraordinary centralization of political and economic functions exerted by a dominant centre over many others (Berry 1973; Smith 1976; Johnson 1977; Kowalewski 1982, 65; Paynter 1982; Falconer and Savage 1995, 40; Ades and Glaeser 1997; Drennan and Peterson 2004). By contrast, in a convex distribution there are many large settlements of roughly the same size in proportion to the number of small settlements. This could indicate population dispersion throughout a given area in sites that are of similar size and thus more competition and less integration between communities (Johnson 1980; Paynter 1982; Falconer and Savage 1995; Wossink 2009, 63-64; Crema 2013 and 2014). On the other hand, there can be other interpretations of such patterns. For instance, limited conflict encourages more widespread settlement and movement, while concentrated settlement could occur due to conflict. In addition, convex distributions are often the result of pooling more than one settlement system in the same analysis and consequently convexity indicates the existence of several independent communities (Johnson 1977). In yet another attempt at rank-size interpretation, some have argued that a convex distribution may result in a stepwise ranking, which may reflect a central place settlement system where highest-order large sites of equivalent political-economic function are equivalent in size (see Crumley 1976; Johnson 1977; Falconer and Savage 1995, 40-41). The primo-convex distribution could indicate the contemporaneous presence of two distinct settlement systems in a region: a centralized system (the primate upper distribution) superimposed on a lower level system loosely integrated or central place organization (the convex lower curve; Johnson 1977 and 1980; Falconer and Savage 1995, 41). The double-convex distribution either indicates multiple settlement systems operating on two different rank levels within a single region or derives from pooling two primate distributions into the same window of analysis (Falconer and Savage 1995, 52; see Fig. 5e; Falconer and Savage 1997, 235). 


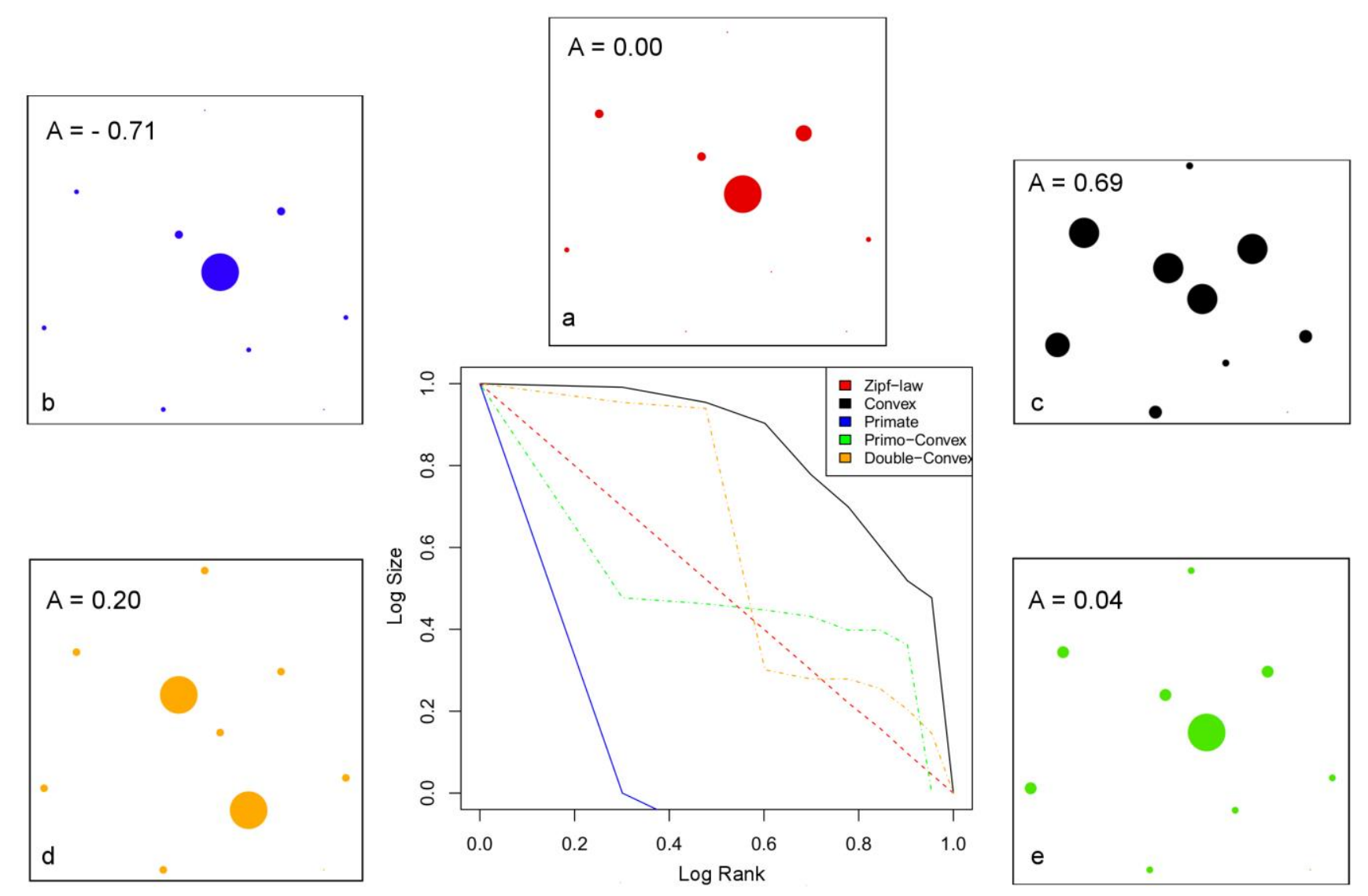

Figure 3. Different examples of rank-size curves and settlement patterns: Zipf-Law (a, red), Primate (blue, b), Convex (c, black), Double-Convex (d, orange), and Primo-Convex (e, green).

Several authors have used basic statistical analysis to test the significance of deviations from Zipf's law in observed settlement size distributions (cf. Falconer and Savage 1995; Savage 1997). Drennan and Peterson (2004), instead of using K-S tests and/or Monte Carlo sampling, introduced a useful summary statistic in this regard. They propose an $A$-coefficient, which calculates the area of the shape of the rank-size curve above and below a standardised log-log plot (see also Wossink 2009, 62-63, 89-91; Crema 2013 and 2014 for the application of this method). This can be achieved by first scaling the rank-size plot, so that the plot has a square shape and the Zipf's law is the diagonal cutting the square into two parts of equal size (Fig. 4). In this way, the $A$ value represents the portion of the shaded area between the Zipf's law line and the observed rank-size curve (see Fig. 4). Hence, the area above the Zipf's law curve and below the observed rank-size curve $(A l)$ will have positive values (Fig. 4), and then the area below the Zipf's law curve and above the empirical data (A2) will have negative values (Fig. 4). Notice that the maximum value for $A 1$ is by definition 1 , while $A 2$ could exceed -1 for strongly primate systems where one or more observed settlements are smaller than the expected smallest settlement predicted by the Zipf's law. According to this method, convex settlement size distributions will have positive $A$ values (Fig. $3 \mathrm{c}$ ), while primate curves have negative $A$ values (Fig. 3b). Even though the $A$ values are useful to assess quantitatively convex and primate curves, they do not provide any information about the shape of the observed settlement size distributions because different rank-size curves can produce similar $A$ values. This is the case of a primo-convex size distribution, where the difference between the positive $A 1$ values of a convex curve and the negative $A 2$ values of a primate curve can produce an overall $A$ value close to 0 (see Fig. 3e) Therefore, the calculation of $A$-coefficient must always be combined with the visual inspection of the size distribution. 


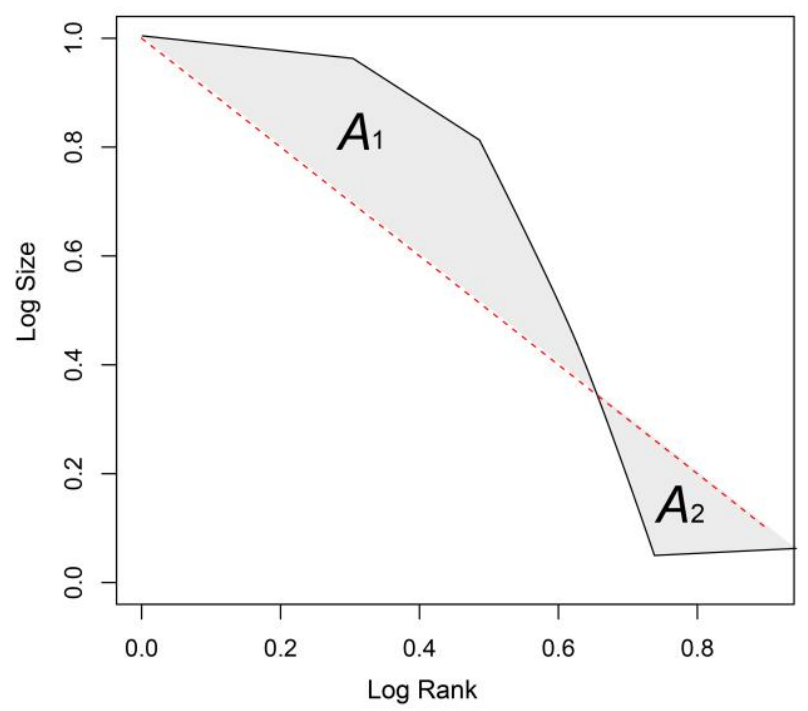

Figure 4. Areas in a rank-size graph used as positive $\left(A_{1}\right)$ and negative $\left(A_{2}\right)$ components of the coefficient A.

Because Drennan and Peterson noticed that the $A$-coefficient is strongly affected by the sampling frame, they suggested the use of a bootstrap statistical technique to test the statistical significance of the $A$ values (Drennan and Peterson 2004, 539-543). This technique calculates the confidence interval of $A$ values by resampling with replacement the observed settlement sizes with 1000 samples randomly selected. Each sample draws the same number of settlement observations as the original observed dataset, but duplicates the result of some observations, while others are omitted. For each of the 1000 samples, the resulting $A$-coefficient is calculated and readjusted in order to produce a confidence range within the $A$ value of the original size distribution will probably fall. The resulting distribution is not always normally shaped, and thus a quantile-based definition of the $95 \%$ confidence interval should be used. If the confidence interval is narrow, it is very likely that the observed pattern depicts a good picture of the reality. On the other hand, if the confidence interval is wide, we have to recognise that the observed pattern provides just a fuzzy picture of its real dynamic.

Archaeologists must be particularly careful when applying rank-size analysis to a given study area. It is most profitable when the spatial extent of a specific settlement system is known. In contrast, failure to identify its boundaries can heavily distort the results. This is a problem for archaeologists, who often deal with data from arbitrarily defined regions. In fact, defining exactly the boundaries of a settlement system in a given period is potentially a fruitless task, and the observed settlement patterns in a specific region should be considered only as a sample of larger spatial systems. It is therefore very likely that pooling more than one settlement system in the same analysis will result in convex settlement size distributions (Johnson 1977, 498). Drennan and Peterson $(2004,535-539)$ have emphasized this problem by comparing the results of rank-size analyses obtained with sample blocks of four different sizes. Therefore, smaller sample blocks are the least convex (see Fig. 5a-d), while larger blocks result in increasingly convex rank-size curves (Fig. 5e-g). Therefore, it is rather clear how samples of different size can determine settlement patterns occurring at different spatial scales of the analysis (see various examples in Fig. 5). Put simply, the larger the window of analysis the higher the chance of pooling more than one settlement system and then obtaining more convex rank-size curves. With these premises in mind, researchers must be aware of spatial patterning at different scales and possibly break down a larger original study area into smaller window analyses in order to detect how settlements patterns change at the local level. 


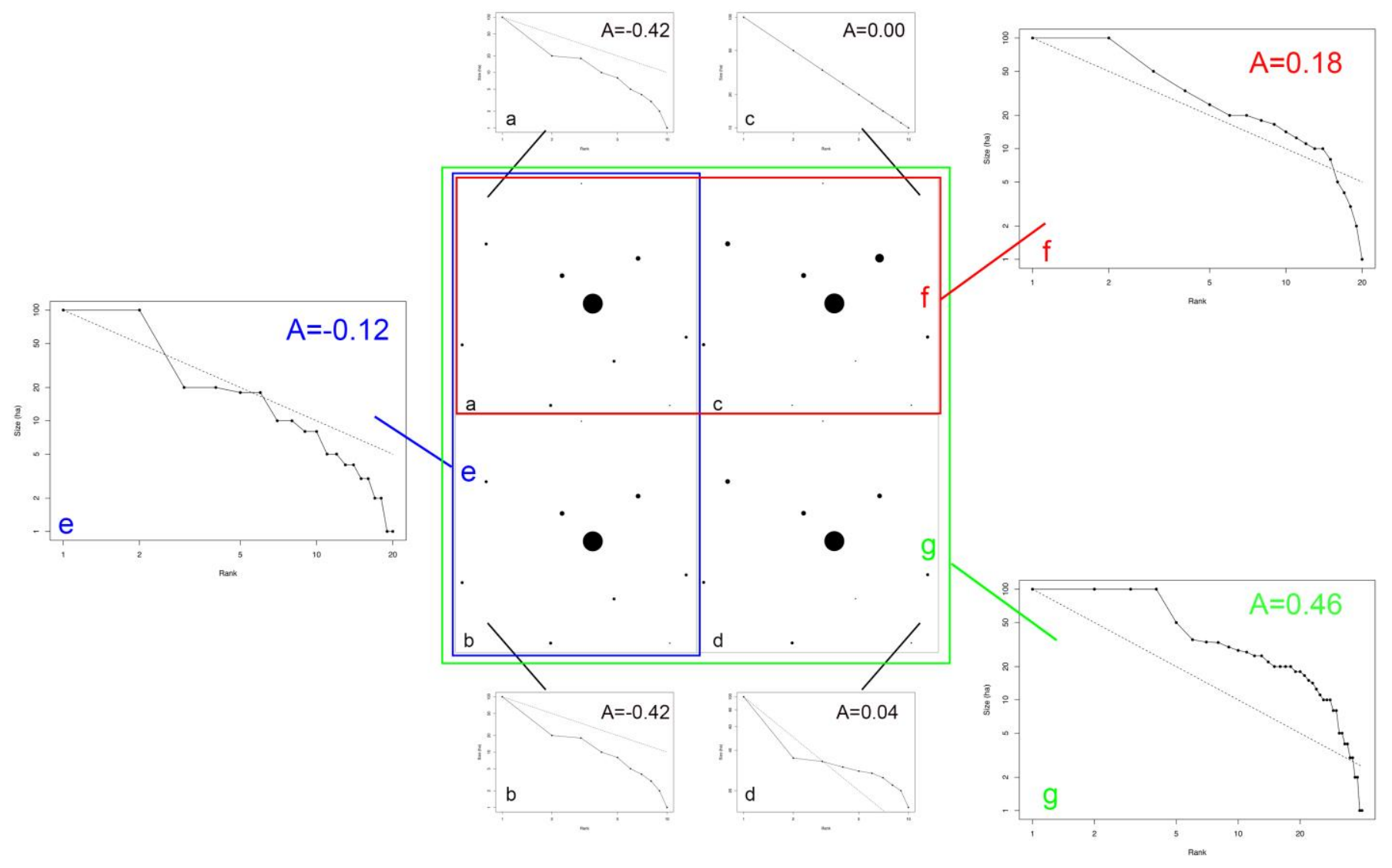

Figure 5. Schematic representation of how changing spatial scales of the analysis result in different settlement size distributions. Settlement size distribution on a local scale: Primate (a and b), Zipfian (c), and Primo-Convex (d). Rank-size curves with larger windows of analysis: Double-Convex (e), and Convex (f and g).

\section{$3.2 k$-means clustering}

The use of $k$-means as a partitioning clustering technique is justified by the fact that in city-states cultures clusters of settlements around prominent urban centers may represent an approximation of spatially defined polities (see Hodder and Orton 1976, 85; Charlton and Nichols 1997; Hansen 2000, 17; Hansen 2002, 13; Thuesen 2000 and 2002; Pollock 2001, 194-195; Strange 2002; Savage and Falconer 2003, 35; Garfinkle 2013; Ur 2013, 139-147). With this premise in mind, I do not assume that the detected clusters are to be considered as a straightforward political map of the case studies under investigation, but rather as a useful spatial approximation for understanding at which geographical scale a well-integrated settlement system is observed during the MBA in CA and the KT.

Spatial $k$-means clustering is a method quite often used in archaeology for analyzing spatial scattering of points at both intra-site and inter-site scale of analysis (see Koetje 1987; Blankholm 1991; Roberts and Parfitt 1999; Vaquero 1999; Ladefoged and Pearson 2000; Savage and Falconer 2003, 35-39; Dixon et al. 2008; Lemke 2013). Recently Baxter (2015, 2-3), in his review comparing different spatial clustering methods, has stated that some critiques on $k$-means have been overstated and that exploring different cluster solutions $(k)$ can be, instead, very useful if framed into a multiscalar approach. 
The $k$-means method attempts to group points into a specified number of $k$ clusters by minimizing the intra-cluster variance and maximizing the inter-cluster distances (Kintigh and Ammerman 1982; Kintigh 1990, 184-185). The locations of the $k$ centroids are the result of an iterative process, where the $k$-means algorithm ${ }^{4} 1$ ) locates $k$ centroids randomly, 2) assigns each point to its closest centroid, 3 ) recalculates the centroids as the mean of all points coordinates in a cluster, 4) and repeats steps 2 and 3 until the resetting of the centroids no longer changes, or the maximum number of iterations (I used 100) is reached. Once all points have been grouped, each cluster's sum of squared error (SSE) is calculated. SSE is the sum of the squared Euclidean distance between each member of a cluster and its cluster centroid and can be seen as a measure of within cluster's variance (Kintigh and Ammerman 1982, 39; Kintigh 1990, 185). Clearly, for a data set, the greatest SSE occurs when all points belong to one cluster, and it is equal to zero when each point constitutes its own cluster. In fact, as the number of clusters increases, the SSE (or variance) decreases because the size of the clusters is smaller and, therefore, the points within each cluster are closer. One of the greatest drawbacks of $k$-means analysis is to know the number of clusters in advance. A common way to determine the optimal number of clusters is to plot in a graph the SSE (or its logarithm) against an increasing number of cluster solutions $(k)$, and to see at which point the rate of reduction of the SSE begins to decline significantly, thereby creating an inflection point or "elbow" in the plot (see Kintigh 1990, 185, Fig. 16; Ladefoged and Pearson 2000, Fig. 4). However, in situations where the points distributions are not highly clustered, there is not a clear inflection point in the plot of the SSE against the number of clusters $(k)$. One further solution is the average silhouette method, which determines how well each point lies within its cluster (see Rousseeuw 1987; Kaufman and Rousseeuw 1990). Average silhouette method computes the average silhouette of observations for different values of $\mathrm{k}$. The optimal number of cluster $(k)$ is the one that maximizes the average silhouette width over a range of possible values for $k$.

\section{Results}

In this section, I will first show the results produced by performing rank-size analyses on the KT and CA and assess comparatively any difference in the observed patterns between them ${ }^{5}$. Second, I will break down each study area into smaller window analyses in order to detect how settlement size distributions change at a local scale. Third, rank-size analysis will be performed on the spatial clusters detected by applying $k$-means partitioning technique.

\subsection{The Khabur Triangle versus central Anatolia}

Figures 6 and Table 2 provide a picture for each study area of the most central group of settlement sizes (in hectares). We can see that the midspreads of the KT (the fifty percent of values between the 3rd and the 1st quartiles values; that is between 1 and 3.1 ha) and CA (between 1 and 2.8) match almost perfectly, and the values of median (1.7 vs. 1.5) differ just minimally. A Whitney-Wilcoxon test shows ( $\mathrm{p}$-value $=0.09$ ) that there is little difference between the KT and CA in terms of the variability of observed settlement sizes.

\footnotetext{
${ }^{4}$ I used the algorithm of Hartigan and Wong (1979) in R statistical computing language (https://www.r-project.org).

${ }^{5}$ The two present study areas have been designed and adapted to the boundaries of the archaeological surveys carried out in the Khabur Triangle and in central Anatolia.
} 


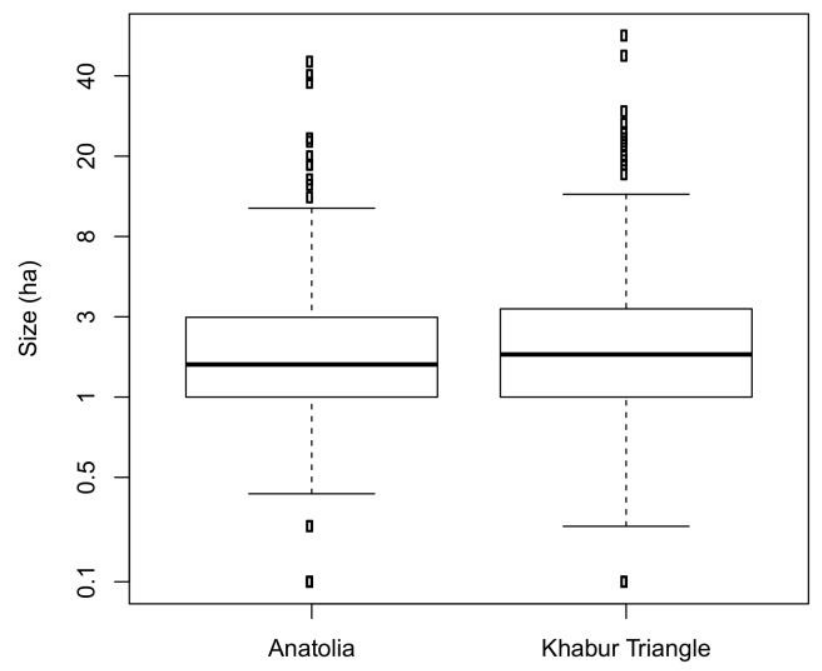

Figure 6. Box and whisker plot of size (in hectares) of Middle Bronze Age settlements in the Khabur Triangle and in central Anatolia.

\begin{tabular}{|c|c|c|c|c|c|c|c|c|}
\hline Region & $\begin{array}{c}\text { no. } \\
\text { sites }\end{array}$ & $\begin{array}{c}\text { Minimum } \\
\text { site size }\end{array}$ & $\begin{array}{c}\mathbf{1}^{\text {st }} \\
\text { quartile }\end{array}$ & median & mean & $\begin{array}{c}3^{\text {rd }} \\
\text { quartile }\end{array}$ & $\begin{array}{c}\text { St. } \\
\text { dev. }\end{array}$ & $\begin{array}{c}\text { Maximum } \\
\text { site size }\end{array}$ \\
\hline $\begin{array}{c}\text { Central } \\
\text { Anatolia }\end{array}$ & 440 & 0.1 & 1 & 1.5 & 2.7 & 2.8 & 5.47 & 55 \\
\hline $\begin{array}{c}\text { Khabur } \\
\text { Triangle }\end{array}$ & 439 & 0.1 & 1 & 1.7 & 3.2 & 3.1 & 6.62 & 90 \\
\hline
\end{tabular}

Table 2. Summary of central tendency and dispersion of settlements size (ha) in central Anatolia and in the Khabur Triangle in the Middle Bronze Age.

Figures 7a and 10a show a rank-size analysis for each study area. At first glance, both size distributions appear similarly convex. For the KT, the calculation of $A$-coefficient (0.26) and the $95 \%$ confidence error range $(0.15-0.50)$ from the bootstrap technique tell us that the rank-size curve is convex (Fig. 7a). For CA, the $A$-coefficient (0.31) and the $95 \%$ confidence error range (0.24-0.53) show that the rank-size curve is significantly convex (Fig. 10a).

Therefore, both results in the KT and CA show a convex distribution for settlement size and rank. These results indicate that there is little political and economic integration among different independent and competing settlement systems occurring in the KT and CA. This could well reflect the fragmented political situation occurring in both areas in the Middle Bronze Age, where citystates fought with each other and shifted alliances for exerting their power over the surrounding areas.

\subsection{The Khabur Triangle}

After performing the above analysis on the entirety of the two study regions, it is worth breaking down each region into smaller areas in order to assess how the settlement size distributions change on a local scale. First, we can divide the KT into an eastern (to the east of the Wadi Jaghjagh) and a western part (to the west of the Wadi Jaghjagh) and then perform rank-size analysis for each of these two areas separately (see Fig. 7b-c). The choice to split this region into two sub-areas is based on a debate over the past two decades about perceived differing sites densities in the eastern and western KT during the Middle Bronze Age (see Lyonnet 1996 and 2000; Wilkinson 2002; Fleming 2004; Ristvet 2005, 123-124; Ristvet 2012). This difference has been explained as due to presence of a more nucleated settlement pattern and small, more pastoral kingdom that made up the Ida- 
Maraş confederacy in the western KT (Charpin and Ziegler 2003, 53; Durand 2004, Fleming 2004), and a more dispersed settlement pattern characterised by more numerous and larger settlements in the eastern KT (Charpin 1987; Ristvet 2008). Two further sub-areas matching with the boundaries of the archaeological surveys carried around Tell Brak (Wright et al. 2007, see also Colantoni 2012) and Tell Leilan (Ristvet 2005) have been subject to rank-size analysis (Fig. 7d-e).

\begin{tabular}{|c|c|c|c|c|c|c|c|c|}
\hline Region & $\begin{array}{c}\text { No. } \\
\text { sites }\end{array}$ & $\begin{array}{c}\text { Minimum } \\
\text { site size }\end{array}$ & $\begin{array}{c}\mathbf{1}^{\text {st }} \\
\text { quartile }\end{array}$ & median & mean & $\begin{array}{c}\mathbf{3}^{\text {rd }} \\
\text { quartile }\end{array}$ & $\begin{array}{c}\text { St. } \\
\text { dev. }\end{array}$ & $\begin{array}{c}\text { Maximum } \\
\text { site size }\end{array}$ \\
\hline West KT & 141 & 0.1 & 0.8 & 1.5 & 2.3 & 3 & 3.71 & 30 \\
\hline East KT & 298 & 0.1 & 1 & 1.8 & 3.4 & 4 & 6.84 & 90 \\
\hline
\end{tabular}

Table 3. Summary of central tendency and dispersion of settlements size (ha) in the western and eastern Khabur Triangle in the Middle Bronze Age.

Table 3 highlights the fact that there are indeed far more settlements and a greater diversity of settlement sizes in the eastern KT, where the largest sites have a bigger extent of the largest sites located in the western KT. We can see that the midspreads of the western KT (between 0.8 and 3 ha) and of the eastern KT (between 1 and 4) do not differ strongly, and the values of median (1.5 vs. 1.8 ) differ just minimally. A Whitney-Wilcoxon test shows ( $p$-value $=0.01)$ a statistically significant difference in site size distribution between the eastern and western parts of the KT. This can be explained by the fact that, overall, the settlements in the eastern KT are larger than those in the western KT. In a natural log scale the rank-size curves of eastern and western KT are convex and appear very similar except for the scale of magnitude (Fig. 7b-c). Then, the $A$-coefficient has been calculated on both areas. For the West KT the calculation of $A$-coefficient $(0.28)$ and the $95 \%$ confidence error range $(0.17-0.55)$ from the bootstrap technique tell us that we are $95 \%$ confident that the rank-size curve is convex (Fig. 7b). In the East KT, the $A$-coefficient $(0.22)$ and the $95 \%$ confidence error range (0.10-0.49) show that the rank-size curve is significantly convex (Fig. 7c). Furthermore, a log-scale plot of the rank-size curve of the area around Tell Brak shows a primoconvex distribution with the overall $A$-coefficient (0.27) resulting in the difference between the positive $A 1$ values of the convex curve $(0.30)$ and the negative $A 2$ values of the primate curve $(0.03$; Fig. 7d). The $95 \%$ confidence error range for A1 (0.12-0.62) and A2 (-0.01- -0.08) shows that the rank-size curve is significantly primo-convex (Fig. 7d). A rank-size plot of the area around Tell Leilan shows a double-convex distribution of settlement sizes and the calculation of an overall $A$ coefficient $(0.11)$ and the $95 \%$ confidence error range $(-0.07-0.41)$ shows that the curve is significantly double-convex (Fig. 7e). 

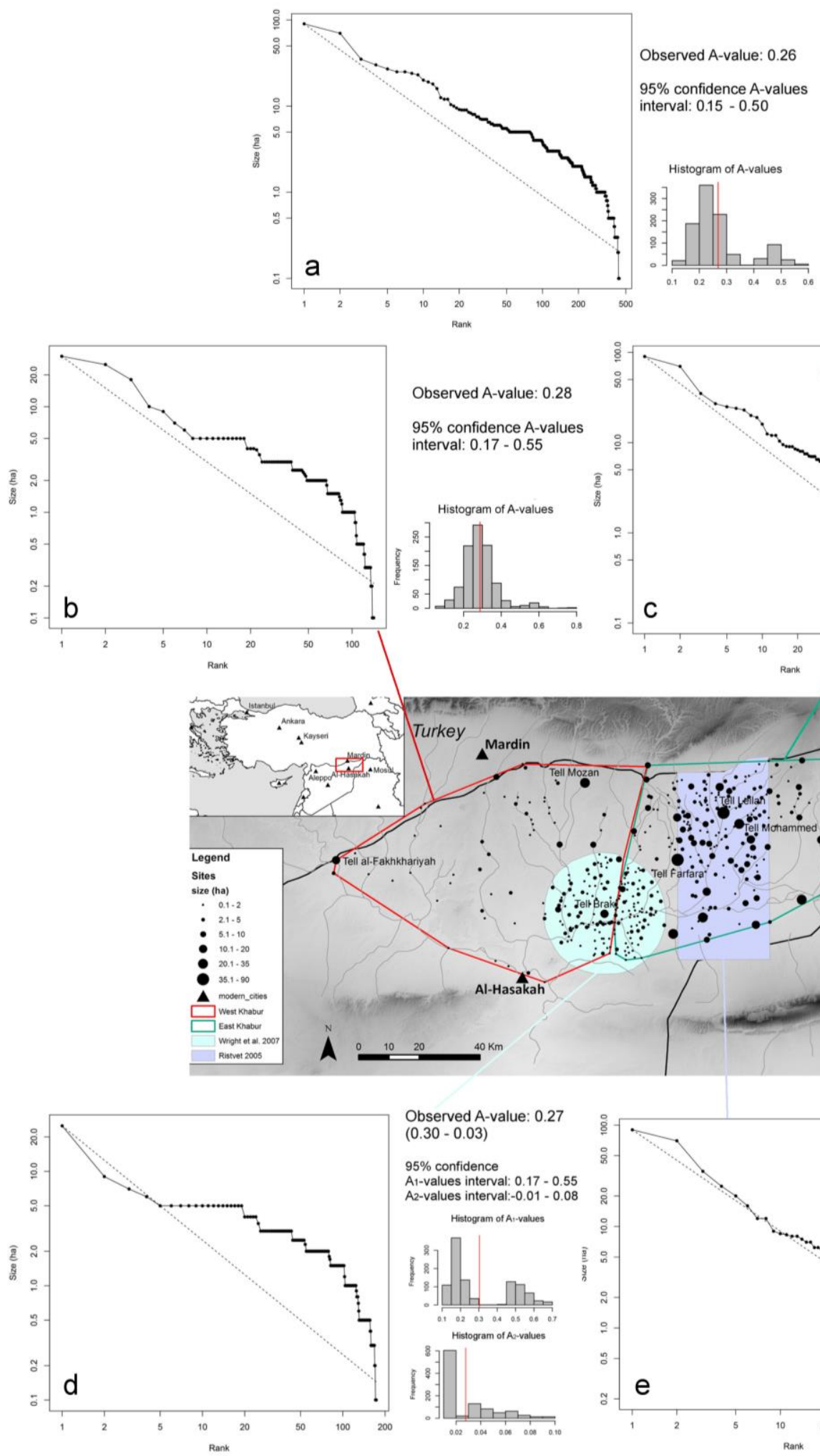

$95 \%$ confidence $A$-values interval: $0.17-0.55$

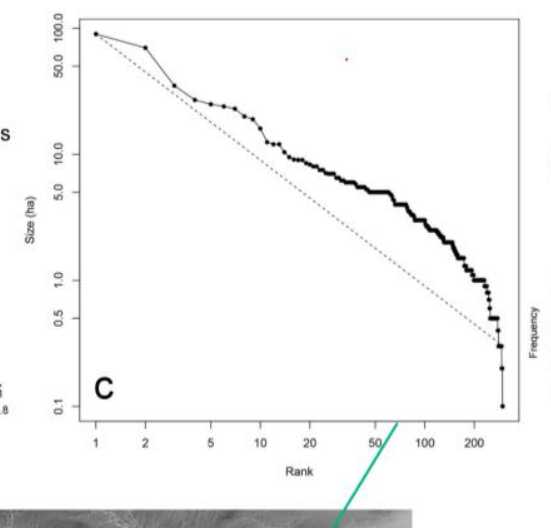

Observed A-value: 0.22

95\% confidence A-values interval: $0.10-0.49$

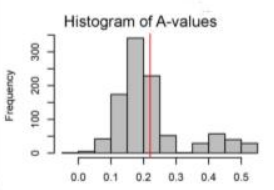

Figure 7. Rank-size graph and histogram of 1000 bootstrapped $A$-coefficient values of the Khabur Triangle dataset. The histograms show the distribution of the simulated $A$ coefficients, along with the observed one (the red line). 
A further step was to use the $k$-means partitioning method in order to break down the study area into smaller window analyses and investigate how settlements size structures change at a more local scale. First, the analysis generated clustering solutions between 1 and 15 ranges. Second, the SSE (and its logarithm) was plotted against an increasing number of cluster solutions $(k)$ in order to choose the optimal cluster level. Fig. 8a-b shows that there is an inflection point or "elbow" on the graph at solution four clusters. This is more evident in Fig. 8b, where the rates of decline of the SSE drastically decreases at four clusters. In order to be sure about the cluster solution $(k)$, I computed the average silhouette of observations for different values of $\mathrm{k}$. The resulting graph (Fig. 8c) shows the highest average silhouette width at two and four clusters. Because the two-cluster solution would basically divide the settlements into two partitions roughly corresponding with the sub-areas Western and Eastern KT discussed above, and so not useful for the purpose to scale down our analysis, the four-cluster solution has been chosen as the optimal one.
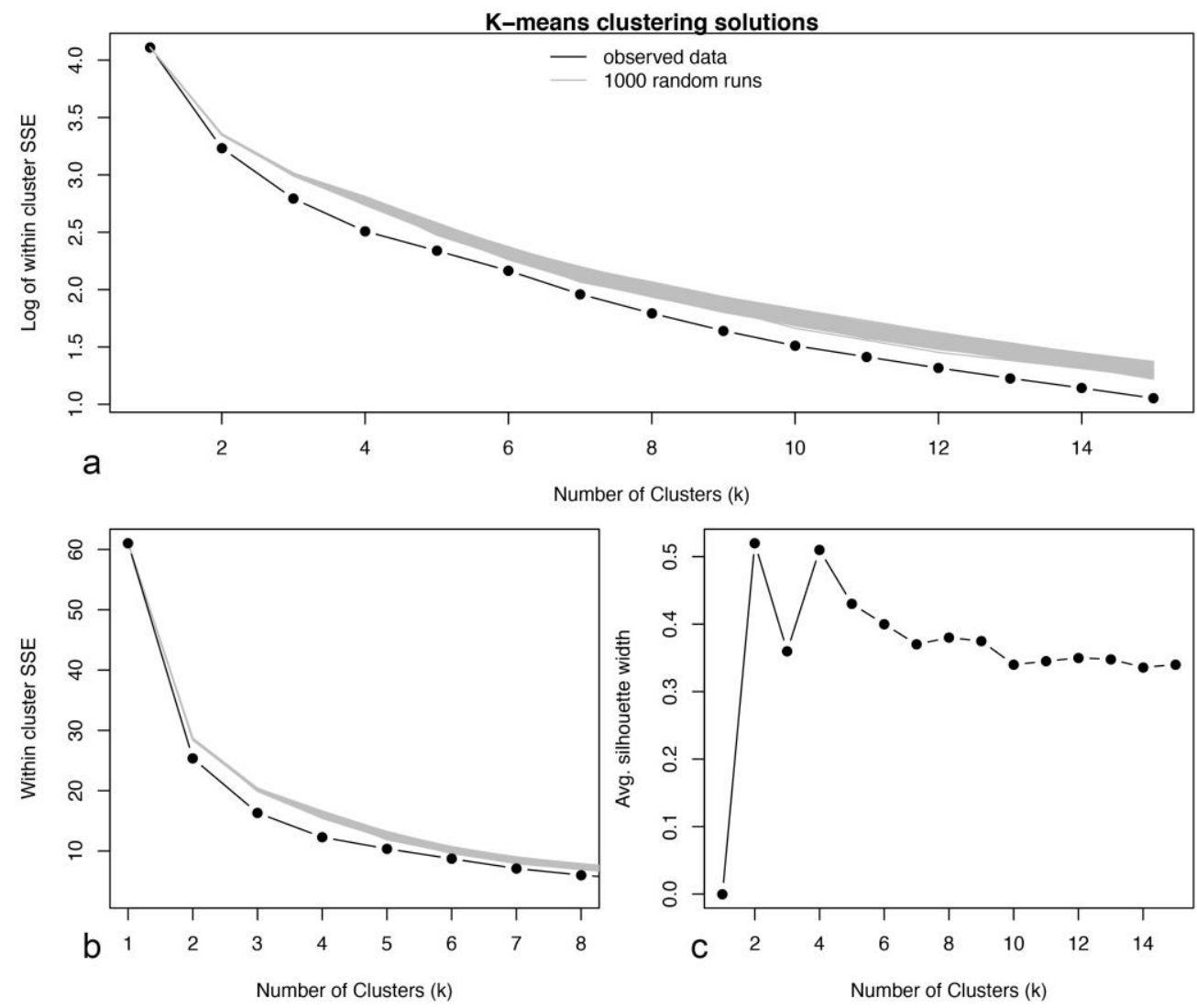

Figure 8. Graph of the $\log$ (a) and normal value of SSE (b) for each cluster solution $(k)$. Average silhouette width for the cluster configurations (c).

Finally, the SSE plot of the observed data have been compared with the SSE plots of 1,000 randomized data in order to assess if the settlements of the KT are significantly clustered (see Kintigh and Ammerman 1982, 46-47; Kintigh 1990, 185) ${ }^{6}$. Randomisation is accomplished by creating new datasets where the eastings (x) and northings (y) of the observed data are drawn separately and then randomly associated (Kintigh and Ammerman 1982, 45-46; Kintigh 1990, 185). Therefore, each randomized dataset will have the same mean and standard deviation on each spatial dimension ( $\mathrm{x}$ and $\mathrm{y}$ ) and the total SSE as the observed data. If the settlements are significantly clustered, the SSE of the observed data will be below the envelope of the randomized data (in grey

\footnotetext{
${ }^{6}$ This was done by using a modified version of Peeples' script written in R for $k$-means clustering analysis (2011).
} 
in figure 8a-b). Otherwise, it will fall within the envelope of random data. The Fig. 8a-b shows that the settlements are significantly clustered at each cluster solution $(k)$. After detecting the optimal cluster solution $k$, I performed a fuzzy $k$-means. This method allows addressing some drawbacks of the $k$-means as "crisp" clustering method such as the tendency to produce circular clusters of similar size and the inability to deal with noise (e.g. points belonging to no cluster, see discussion in Baxter 2009 and 2015, 4). To do so, I used the R statistical language's package vegclust (De Cáceres 2016; De Cáceres and Wiser 2016) in order to assign a fuzzy cluster membership for each settlement. In fact, for some sites the distance to the closest cluster's centroid does not differ much from the distance to second closest one. Fuzzy $k$-means is expressed, for each cluster solution $(k)$, through a degree of membership bounded between 0 (e.g. the settlement does not belong to any cluster at all) and 1 (i.e. the settlement belongs completely to a given cluster). Therefore, I set 0.5 as a threshold to classify all settlements with less than fifty percent of probability to belong to any cluster as noise. Hence, the resulting clusters are represented as convex-hulls in the Fig. 9a.

In the end, the rank-size analysis was performed for each cluster detected in the KT. A log-scale plot of the rank-size curve of the clusters 2 , which almost entirely match with the archaeological survey's area around Tell Brak, shows a significant primo-convex distribution with the overall $A$ coefficient ( 0.27 ) resulting as the difference between the positive $A 1$ values of the convex curve (0.30) and the negative $A 2$ values of the primate curve (0.03; Table 4). Even cluster 1 , which covers a large portion of the western KT, shows a primo-convex curve and a slightly negative $A$-coefficient (0.03, Table 4$)$. As the positive $A 1$ values show a quite wide $95 \%$ confidence interval, it is possible that the pattern could have a higher convexity. In addition, in this case, the settlement size distribution results convex if we remove the 1st ranked site Tell Fakhkhariya (18 ha), which is the westernmost site of the cluster 1 (see Fig. 9a) and could be part of a different settlement system. Cluster 3 is characterized by a rank-size curve slightly convex in its upper portion and then slightly primate and convex in its lower component. The confidence range of both $A 1$ and $A 2$ values suggests that the primateness and convexity of this curve could be more accentuated (see Table 4). Finally, the $A$-coefficient $(0.25)$ and the $95 \%$ confidence error range $(0.10-0.51)$ from the bootstrap technique suggest that the rank-size curve is significantly convex for the cluster 4 (Fig. 9a, Table 4). It is important to notice that some settlements to the north of the cluster 2 and to the south of the clusters 3 and 4 (see Fig. 9a) have been classified as noise as their cluster membership was not so clear. This result makes sense if you consider that among those "noisy" points there are prominent sites such as Tell Mozan, Dumdum and Hansa. These sites could be the capital cities of different city-states, and it is not surprising that they have not been assigned to any cluster. The fact that they do not constitute a cluster by themselves is biased by the lack of intensive archaeological surveys carried out in their surrounding hinterlands, which results in a very low density of sites. Overall, both the western and eastern KT show a very similar dispersed pattern that could be the result of pooling in the same analysis different competing city-states and petty kingdoms occurring in both areas (Fig. 7b-c). The difference between the two parts of the KT is in the magnitude of the settlement sizes, where the settlements distributed in the eastern KT are far larger than the settlements in the western KT. Nevertheless, if we perform rank-size analysis on a smaller local scale, we can detect some differences between the settlement patterns occurring in the two areas. In fact, the area around Tell Brak to the west of the Wadi Jaghjagh is characterized by a primo-convex distribution, where the largest site (Tell Brak) imposes a centralized system on a lower-level settlement system of satellite communities and medium-small villages (Fig. 7d; Fig. 9, cluster 2). On the other hand, a double-convex curve in the Tell Leilan area represents the presence of two contemporaneous settlement systems operating within the same region at different scales (Fig. 7e; Figure 9, cluster 3). More precisely, the upper convex curve represents the largest sites of the east KT (Tell Leilan and Tell Farfara) superimposed on a more loosely integrated system (the lower of the two convex curves). 


\begin{tabular}{|c|c|c|c|c|c|c|}
\hline \multicolumn{7}{|c|}{ Khabur Triangle } \\
\hline $\begin{array}{c}\text { Cluster } \\
\text { No. } \\
\text { In the } \\
\text { map }\end{array}$ & $\begin{array}{l}\text { No. } \\
\text { sites }\end{array}$ & $\begin{array}{l}\text { Area } \\
\mathrm{Km} \text { sq. }\end{array}$ & $\begin{array}{l}\text { Largest } \\
\text { site } \\
\text { (approx. } \\
\text { ha) }\end{array}$ & $\begin{array}{l}\text { Observed } \\
\text { A-coefficient }\end{array}$ & $\begin{array}{c}\text { Error range } \\
(95 \% \text { confidence })\end{array}$ & Curve Shape \\
\hline 1 & 39 & 2,625 & 18 & $\begin{array}{c}-0.03(0.04-0.07) \\
\left(A_{1}-A_{2}\right)\end{array}$ & $\begin{array}{c}A_{1}=0.49(0.1-0.50) \\
A_{2}=0.23(-0.01--0.24)\end{array}$ & Primo-Convex \\
\hline 2 & 173 & 1,352 & 20 & $\begin{array}{c}0.27=0.30-0.03 \\
\left(A_{1}-A_{2}\right)\end{array}$ & $\begin{array}{c}A_{1}=0.49(0.12-0.61) \\
A_{2}=0.07(-0.01--0.08)\end{array}$ & Primo-Convex \\
\hline 3 & 105 & 973 & 90 & $\begin{array}{c}-0.07=0.02-0.09 \\
\left(A_{1}-A_{2}\right)\end{array}$ & $\begin{array}{c}\mathrm{A}_{1}=0.49(0.1-0.50) \\
\mathrm{A}_{2}=0.25(-0.01--0.26)\end{array}$ & $\begin{array}{l}\text { Double- } \\
\text { Convex }\end{array}$ \\
\hline 4 & 86 & 1,676 & 35 & 0.25 & $0.41(0.10-0.51)$ & Convex \\
\hline \multicolumn{7}{|c|}{ Central Anatolia } \\
\hline 5 & 19 & 2,861 & 6.3 & 0.23 & $0.42(0.10-0.52)$ & Convex \\
\hline 6 & 25 & 1,995 & 25 & -0.17 & $0.38(-0.06--0.44)$ & Primate \\
\hline 7 & 27 & 1,522 & 7.5 & 0.35 & $0.47(0.14-0.61)$ & Convex \\
\hline 8 & 23 & 1,454 & 10.5 & 0.27 & $0.45(0.05-0.50)$ & Convex \\
\hline 9 & 26 & 2,564 & 15 & $\begin{array}{c}0.03=(0.04-0.01) \\
\left(A_{1}-A_{2}\right)\end{array}$ & $\begin{array}{c}A_{1}=0.39(0.1-0.40) \\
A_{2}=0.16(-0.01--0.17)\end{array}$ & Primo-Convex \\
\hline 10 & 32 & 1,655 & 18 & $\begin{array}{c}0.08=(0.13-0.05) \\
\left(A_{1}-A_{2}\right)\end{array}$ & $\begin{aligned} & \mathrm{A}_{1}=0.54(0.1-0.55) \\
& \mathrm{A}_{2}=0.15(-0.02--0.17)\end{aligned}$ & Primo-Convex \\
\hline 11 & 31 & 1,790 & 24 & $\begin{aligned} 0.06= & (0.14-0.08) \\
& \left(A_{1}-A_{2}\right)\end{aligned}$ & $\begin{array}{c}\mathrm{A}_{1}=0.52(0.2-0.54) \\
\mathrm{A}_{2}=0.21(-0.07--0.28)\end{array}$ & Primo-Convex \\
\hline 12 & 34 & 1,793 & 25 & $\begin{array}{c}0.02(0.07-0.05) \\
\left(A_{1}-A_{2}\right)\end{array}$ & $\begin{array}{c}\mathrm{A}_{1}=0.38(0.2-0.40) \\
\mathrm{A}_{2}=0.16(-0.01--0.17)\end{array}$ & Primo-Convex \\
\hline 13 & 37 & 3,934 & 55 & -0.53 & $-0.76(-0.23--0.99)$ & Primate \\
\hline 14 & 18 & 2,190 & 6 & 0.37 & $0.52(0.13-0.65)$ & Convex \\
\hline 15 & 18 & 4,417 & 50 & -1.03 & $1.22(-0.49--1.710)$ & Primate \\
\hline 16 & 18 & 1,779 & 20 & -0.59 & $0.90(-0.26--1.16)$ & Primate \\
\hline
\end{tabular}

Table 4. A-coefficient values and bootstrapped error ranges for log scale rank-size curves of the clusters in the Khabur Triangle (KT) and central Anatolia (CA). 

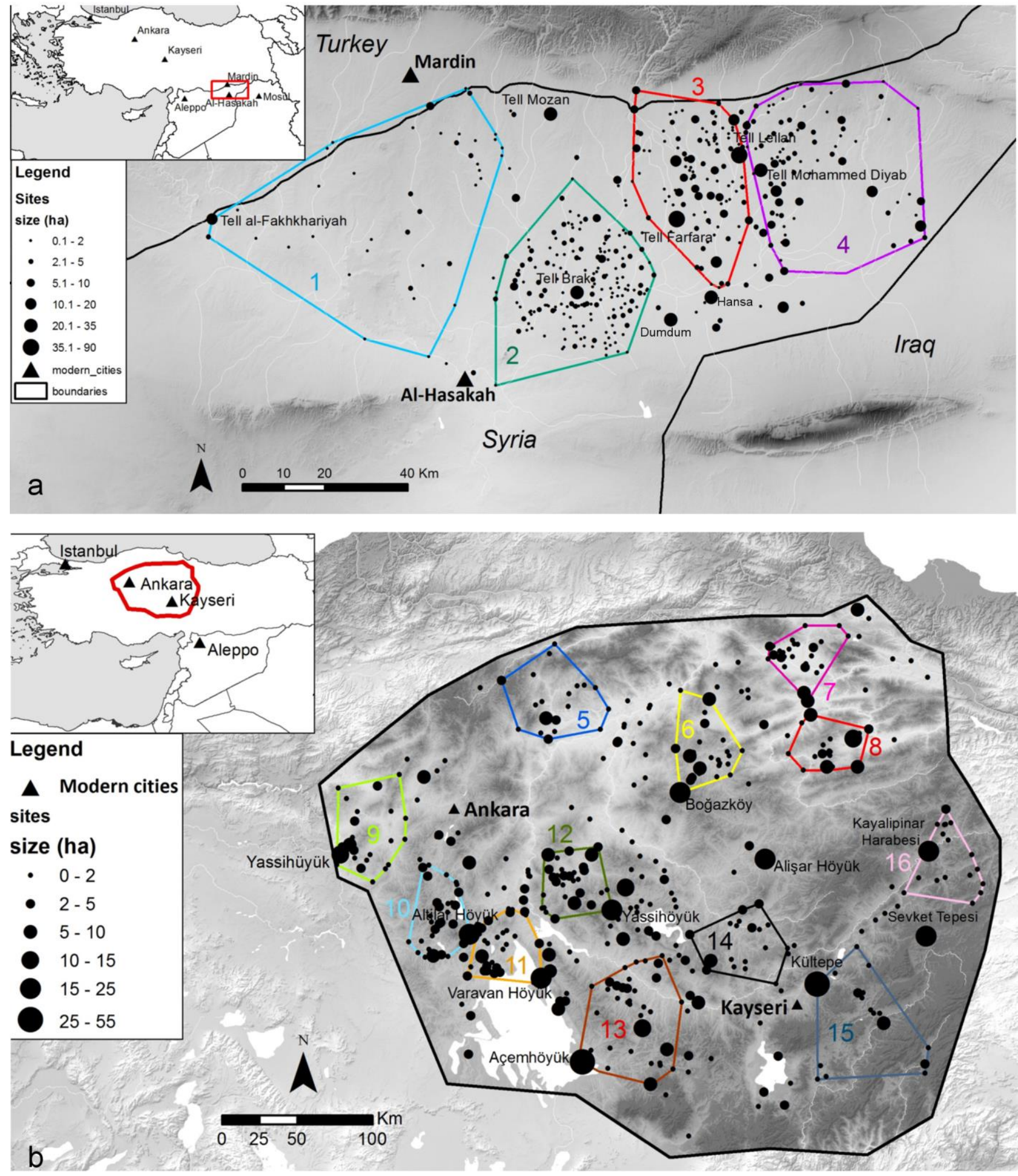

Figure 9. Plot of the 4-cluster solution in the Khabur Triangle (a) and of the 12-cluster solution in central Anatolia (b). The points outside the clusters are noise. 


\subsection{Central Anatolia}

We can now perform the same break-down of the central Anatolian region into smaller areas in order to assess how the settlement size distributions change at smaller local scales. The study area can usefully be divided into four smaller windows of analysis matching with the boundaries of archaeological surveys carried out in the area around Kayseri (see Kulakoğlu et al. 2009-2011, Fig. 10b), Varavan Höyük and Altilar Höyük (Omura 1997 and 2003-2007; Fig. 10e), Yassihöyük (Omura 2001-02 and 2008; Fig. 10d), and with a geographically defined area around Boğazköy in the Bozok plateau between the Delice River to the west and the Yeşilırmak River to the north-east (see Fig. 10c).

A log-scale plot of the rank-size curve of the area around Kayseri shows a primate curve with the A-coefficient (- 0.40) and the 95\% confidence error range (-0.09-0.79) suggesting that the ranksize curve is primate (Fig. 10b). This primate distribution might be stronger if we remove the 2 th ranked site Sevket Tepesi ( $25 \mathrm{ha}$ ), which is the easternmost site of the window of analysis and could be part of a different settlement system (see Fig. 10b). In the area surrounding Boğazköy, the ranksize curve is primo-convex with the overall $A$-coefficient $(0.2)$ resulting in the difference between the positive $A 1$ values of the convex curve (0.9) and the negative $A 2$ values (0.07) of the primate curve (Fig. 10c). The $95 \%$ confidence error range shows that the settlement size distribution is likely primate (Fig. 10c). Furthermore, a log-scale rank-size curve of the area around Yassihöyük is convex and both the A-coefficient $(0.21)$ and the $95 \%$ confidence error range $(0.04-0.50)$ show a significant convex settlement size distribution (Fig. 10d). A rank-size plot of the area to the north of Tuz Gölü lake shows a double-convex distribution of settlement sizes and the calculation of an overall $A$-coefficient $(0.29)$ and the $95 \%$ confidence error range $(0.10-0.63)$ show that the curve is significantly double-convex (Fig. 10e).

As already done for the KT, the $k$-means partitioning technique was used in order to break down the area into smaller window analyses. The SSE (and its logarithm) was plotted against an increasing number of 15 cluster solutions $(k)$ to choose the optimal cluster level. The Fig. 11a-b shows that the settlements are significantly clustered at each cluster solution $(k)$. Nevertheless, the graph indicates that an inflection point or "elbow" in the SSE curve is not so evident and further evaluation is needed (Fig. 11a-b). The highest average silhouette width is at two and twelve-cluster solutions (Fig. 11c). As in the case of the KT, a two-cluster solution is not so useful for the purposes of this paper because it would divide the settlements into two distinct large partitions respectively to the north and the south of the Kizilirmak River. Thus, a twelve-cluster solution was chosen as the optimal one. The resulting twelve fuzzy clusters are shown as convex-hulls in Fig. 9b. Rank-size analysis of individual clusters shows strong primate distributions for the clusters 6, 13, 15 and 16, where the dominant sites are respectively Boğazköy, Acemhöyük, Kültepe, and Kayalipinar Harabesi (Fig. 9b; Table 4). The clusters 9, 10, 11 and 12 show a primo-convex distribution due to a large settlement in the upper part of the curve superimposed on a tier of many smaller sites of the convex lower curve (Fig. 9b; Table 4). In these three groups, the dominant centres are respectively Yassıhüyük, Altilar Höyük, Varavan Höyük, and Yassıhöyük. Among the clusters detected in Anatolia, four clusters (5, 7, 8, and 14; see Table 4 and Fig. 9b) show significant convex distributions and are characterized by poor settlement integration and the lack of a dominant urban centre. Among the "noisy" points are noticeable Alişar Höyük and Sevket Tepesi, two large sites (approx. 25-20 ha) that could be the dominant centre of two distinct clusters and so city-states (Fi. 9b). As in the case of the KT, the result is biased by the total lack of archaeological sites carried out in the surrounding hinterland of those two sites. Alişar Höyük has been identified with the ancient Amkuka, which during the Old Assyrian period (ca. 1950-1700 BC) was an Anatolian citystate and seat of an Assyrian commercial settlement kārum (Barjamovic 2011, 312-313).

Overall, it seems that in CA most clusters show a high settlement primacy, which is typical of citystates. Only the area to the east of Yassihöyük, between the Delice River to the north and the Kizılirmak River to the south (Fig 9b, cluster 14), and three clusters to the west (Fig. 9b, cluster 5) 
and the east of the Bozok plateau (Fig. 9b, clusters 7 and 8) show a dispersed pattern and a poor integration between communities.
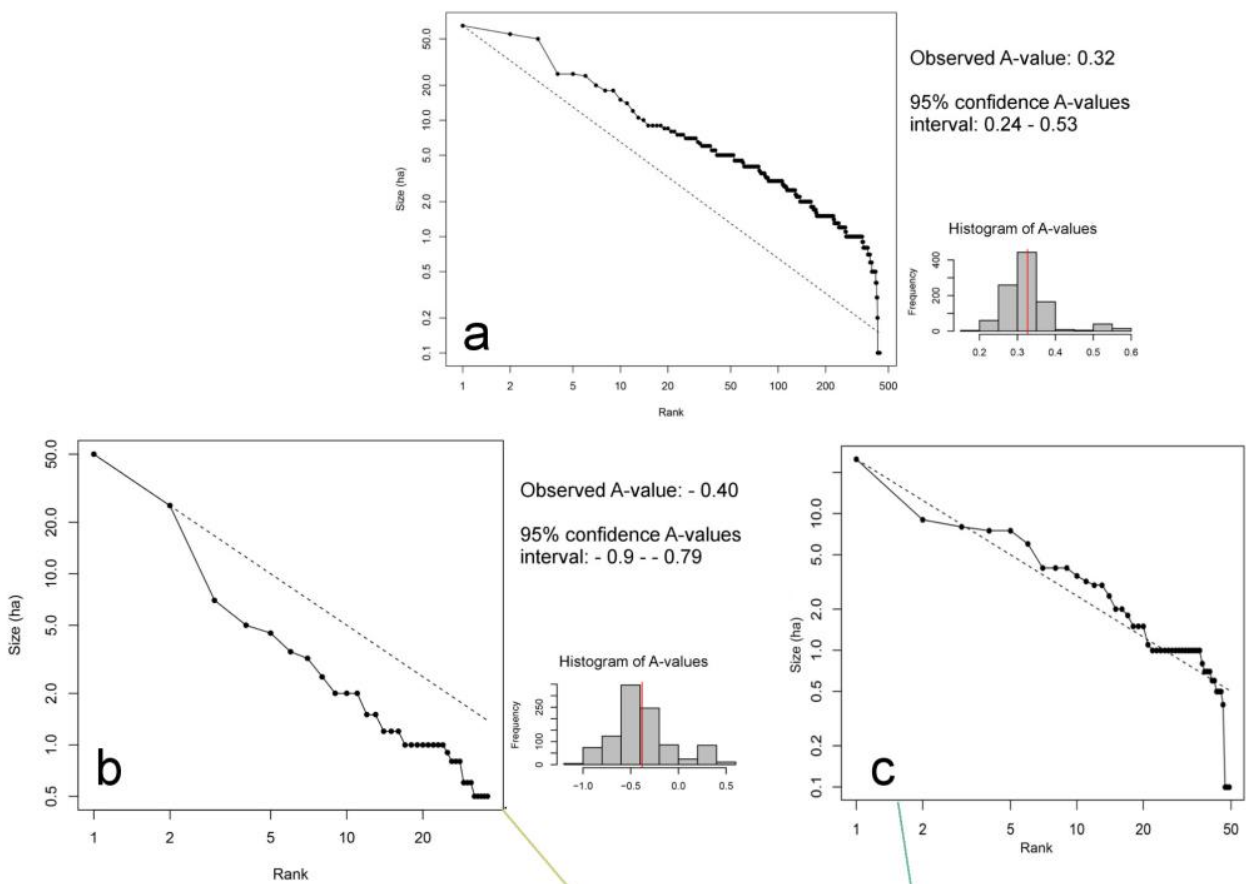

Observed A-value: 0.02

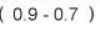

$95 \%$ confidence

A1-values interval:-0.16-0.41

Histogram of A:-values
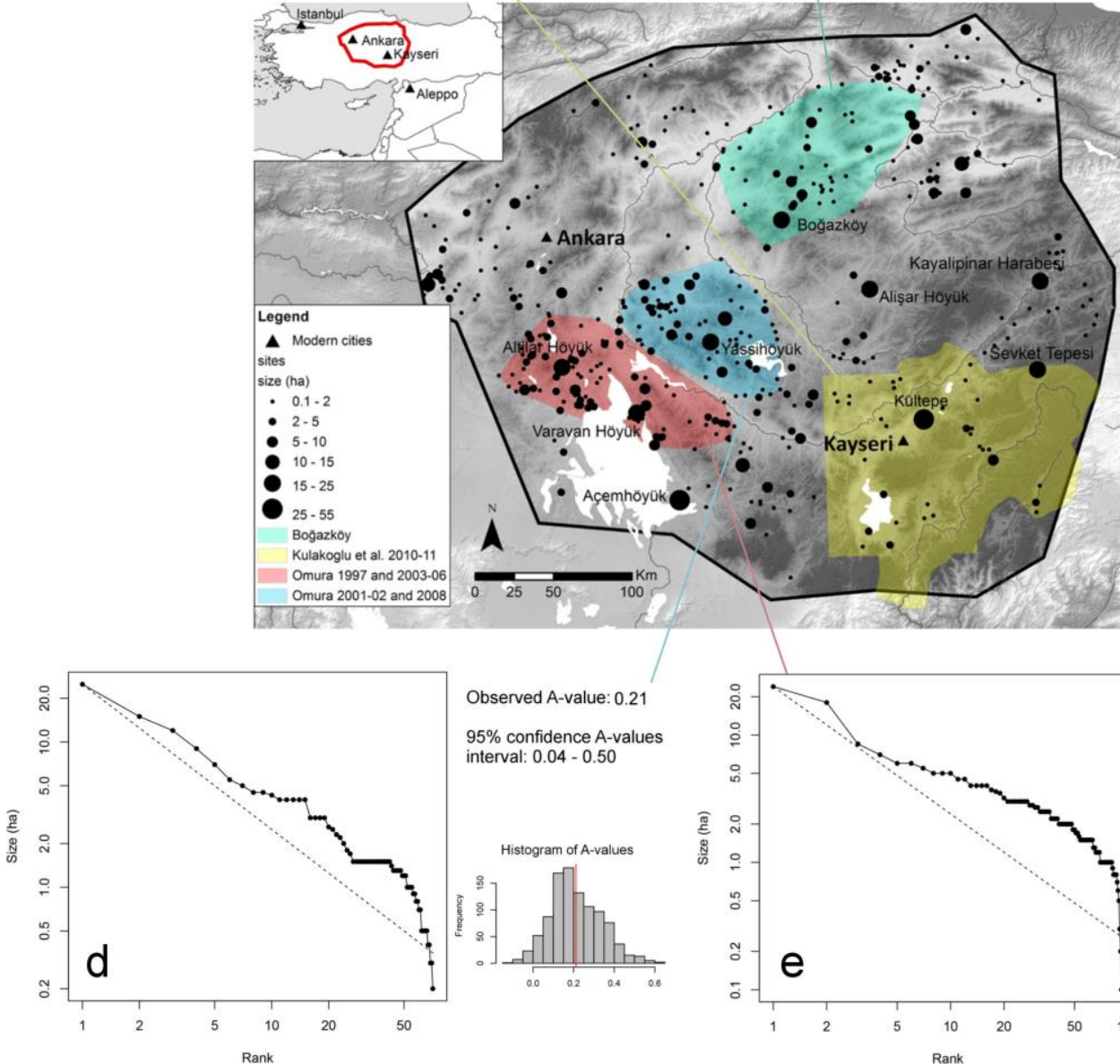

Observed A-value: 0.2

$95 \%$ confidence A-values interval: $0.04-0.50$

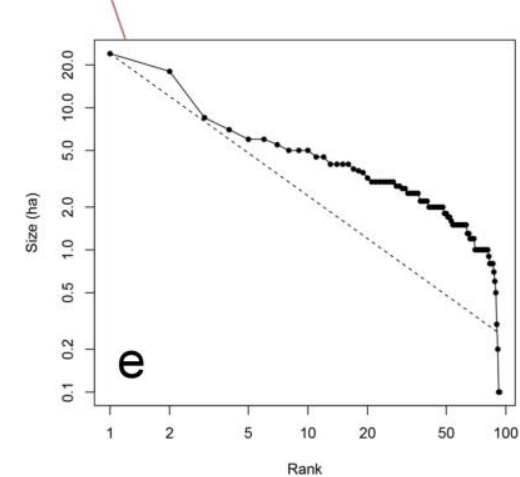

Observed A-value: 0.29

$95 \%$ confidence A-values interval: $0.10-0.63$

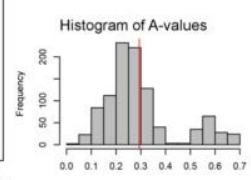

Figure 10. Rank-size graph and histogram of 1000 bootstrapped $A$-coefficient values of central Anatolia dataset. The histograms show the distribution of the simulated $A$ coefficients, along with the observed one (the red line). 

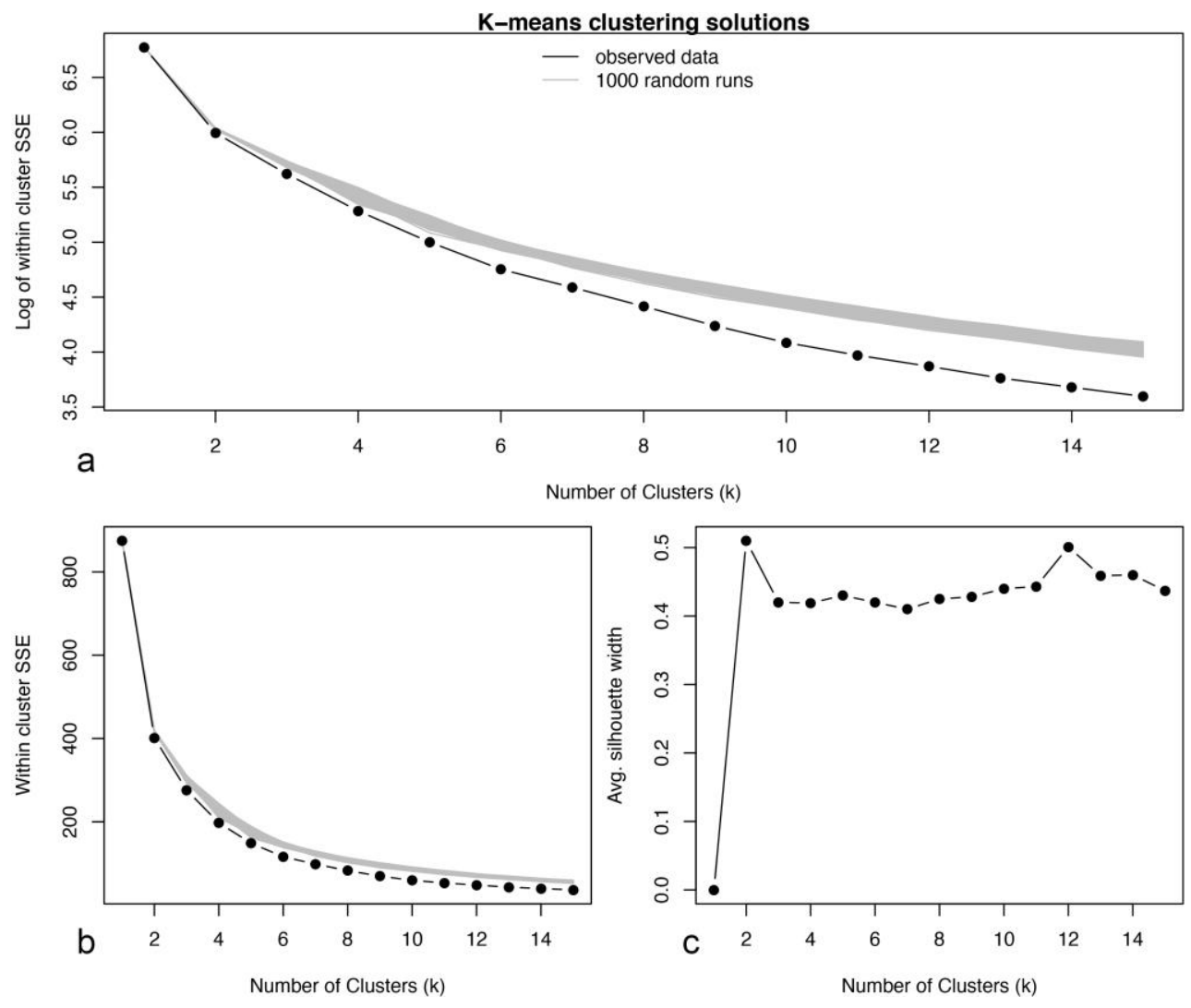

Figure 11. Graph of the log (a) and normal value of SSE (b) for each cluster solution $(k)$. Average silhouette width for the cluster configurations (c).

\section{Discussion}

Despite the surviving archival data, defining the political landscapes of Upper Mesopotamia and central Anatolia in the early second millennium BC remains a big challenge, especially in the light of the uncertainties present in the available archaeological and textual dataset. However, as I showed in this paper, there are advantages in applying a multi-scalar approach to settlement pattern analysis.

I have first provided a global picture of regional settlement patterns occurring in central Anatolia and the Khabur Triangle, and then focused on how settlement size structures change at different spatial scales of analysis. Both central Anatolia and the Khabur Triangle show very similar dispersed settlement patterns when considered as a whole (see Figs. 7a and 10a) but these results can be explained as the consequence of pooling different settlement systems into the same window of analysis. In other words, at this larger regional scale, both central Anatolia and the Khabur Triangle in the Middle Bronze Age are characterized by balkanized landscapes of competing independent polities loosely integrated (for central Anatolia see Veenhof and Eidem 2008, 147-179; Barjamovic 2011, 6; Barjamovic et al. 2012, 48-50; Palmisano and Altaweel 2015a and 2015b; for the Khabur Triangle see Charpin and Ziegler 2003; Veenhof and Eidem 2008, 290-321; Ristvet 2008 and 2012; Palmisano 2015; Palmisano and Altaweel 2015a and 2015b; Altaweel et al. 2015). The second step was to break down these two regions into smaller window analyses matching with the boundaries of some archaeological surveys carried out both in central Anatolia and the Khabur Triangle (Figs 7d-e and 10b-e). However, this approach can be problematic as arbitrarily defined boundaries of survey areas are nearly impossible to encompass specific unitary polities and settlement systems changing across space and time (see discussion in Schiffer et al. 1978; Plog et 
al. 1978, 384; Banning 2002, 22-25; Ur 2010b, 42). In fact, the results show a double-convex distribution in the area around Tell Leilan (Fig. 7e), and convex-distributions (Fig. 10d-e) or not particularly strong primate distributions in central Anatolia (Fig. 10b), which is the result of pooling distinct settlement systems in the same window of analysis. A further step to address this issue was to use fuzzy $k$-means partitioning technique in order to detect clusters to be interpreted as a spatial approximation of city-states' territories (see Fig. 9a-b). The results show that the geographical scale for both the Khabur Triangle and Central Anatolia, at which a well-integrated and centralized settlement system is observed, is the city-state as a compact and modestly-sized political unit characterized by a dominant centre (see Fig 12a-b; Table 4). Therefore, central Anatolia and the Khabur Triangle were marked by a network of politically independent but economically linked and roughly equivalent polities, in which each one controlled its surrounding rural hinterland via more or less obvious forms of centralised control.

The eastern and western parts of the Khabur Triangle show similar dispersed settlement patterns (Fig. 7b-c) that probably reflect the presence of different independent competing city-states in both areas and a central-place settlement structure, where bigger urban centres were surrounded by secondary towns, villages, small farmsteads, and seasonal campsites. At this scale, the difference between the two areas is characterised by the differing size of the largest settlements, with those in the eastern Khabur Triangle having a bigger extent than those in the western Khabur Triangle. The available survey data allow us to investigate more deeply the settlement patterns in Tell Brak and Tell Leilan's areas (respectively the areas surveyed by Wright et al. 2007 and Ristvet 2005), and for Tell Brak's area the settlement system is more nucleated in one big centre (Tell Brak), with a contemporaneous settlement system of nearby satellite medium-small size villages. On the other hand, in the Tell Leilan area, the general settlement pattern appears more dispersed among large settlements of equivalent economic or administrative function (Tell Leilan, Tell Farfara, Tell Mohammed Diyab, Tell Aid, Hansa, and Dumdum) superimposed on a more loosely integrated settlement system of medium-small settlements (Ristvet and Weiss 2010, 27). It also seems that the Khabur Triangle was less densely populated in the western part and more densely populated in its eastern part (see Table 2). This dual pattern has been explained by Ristvet and Weiss (2005 and 2010) as the result of lower rainfall to the west of the Wadi Jaghjagh and a more nucleated pattern of smaller overall settlements, perhaps with closely packed domestic quarters in the western Jazira (e.g. Chagar Bazar, Tell Mozan, and Tell Arbid). This explanation via rainfall is however disputed, as the only fairly slight differences in precipitation from east to west probably cannot explain such marked difference in settlement alone. Weiss and Ristvet's observation about domestic quarter packing could be more plausible but remains difficult to validate given the patchiness of the available archaeological data. Their argument about different population densities occurring in the western and eastern Khabur Triangle remains possible, but could also be the result of the different archaeological survey recovery methods applied to the two areas with no intensive surveys in the west except immediately around Tell Beydar (Ur and Wilkinson 2008; for extensive coverage, see Lyonnet 2000 and Meijer 1986), especially in light of the recent work by Colantoni (2012), which shows a heavily populated area around Tell Brak. On the other hand, this dual pattern remains a possibility, and if valid, could be elucidated with reference to the suggestions in the textual evidence of a rough coalition of kinglets (the Ida-Maraş confederacy) along and to the West of the Wadi Jaghjagh, predominantly sustaining themselves on pastoral or semi-pastoral economy, which would explain the more ephemeral archaeological evidence, and the territory near ŠubatEnlil/Šehna (Tell Leilan), which was mostly agricultural (see Joannés 1996, 344-345; Lyonnet 1996 and 1997; Wilkinson 2000 and 2002; Ristvet and Weiss 2005 and 2013; Lawrence et al. 2015, 1718).

Central Anatolia is mostly characterized by primate rank-size distributions ( 8 clusters out of 12; see Fig. 12a), and the results show that Acemhöyük, Boğazköy, Kültepe, and Kayalipinar Harabesi have strong vertical primacy with one large centre dominating over smaller sites. On the other hand, 
dispersed settlement patterns and no particular predominant urban centres characterize the areas to the north of the central Anatolian plateau, both to the west and the east of the Bozok plateau. This fits well with the central Anatolian political landscape suggested by the texts, which is fragmented into numerous independent city-states during the Old Assyrian Colony Period (ca. 1970-1700 BC; see Barjamovic 2011, 6; Barjamovic et al. 2012, 44-49). It seems that Böğazköy could have naturally exerted a dominant influence within the northern bend of the Delice River, which could also have played as physical and political boundary. Other highly integrated polities seem to emerge to the south of the Kızılırmak River: Acemhöyük, Altilar Höyük, Kültepe; Sevket Tepesi;

Kayalipinar, Varavan Höyük, and Yassihüyük. Instead, across the basin between the Delice and the Kızılırmak Rivers, Yassihöyük could have exerted its power.

The rank-size analysis' results show some differences between central Anatolia and the Khabur Triangle at smaller local scales. In fact, in central Anatolia settlement systems appear more nucleated in large centres dominating their surrounding rural hinterlands and strong political and economic centralization is evident at Acemhöyük, Boğazköy, Kültepe, and Kayalipinar Harabesi (Table 4). On the other hand, in the Khabur Triangle settlement primacy is less strong and polities are more loosely integrated. In central Anatolia, a more remarkable vertical integration is the result of an even spatial distribution of large settlements that could then dispose of large rural hinterland over imposing a more centralized political and economic control. On the contrary, in the Khabur Triangle the largest sites were packed in a smaller plain area, where the lack of marked topographical features (e.g. wide rivers, mountain ranges) could have further enhanced competition between large city-states of comparable size and political prominence and determined unstable territories (cf. Eidem 2000, 257).

Overall, these patterns are to be considered as a "fuzzy" picture of the political landscapes occurring in central Anatolia and the Khabur Triangle in the early second millennium BC. To the lack of a complete picture about settlement patterns from the archaeological survey record, we have to add further uncertainty of chronology and site size estimates due to the conservative characteristic of the early second millennium BC pottery assemblages used as chronological marker (Schoop 2006 and 2009 for a discussion about central Anatolia; see Oguchi 2006 and Kolinski 2014 for the Khabur Triangle) and unwillingness or inability of existing archaeological surveys to offer period-specific size estimates apart some exceptions (see examples for Tell Brak, Tell Beydar and Tell Hamoukar in the Khabur Triangle; Ur 2010b; Ur and Wilkinson 2008; Ur et al. 2007 and 2011). In addition, from textual evidence emerge that city-states were involved in ever-shifting alliances, and fought each other to gain control over strategic resources and "fluid" territory with often ambiguous and not contiguous boundaries (Eidem 2000, 257; Ristvet 2008, 592; Osborne 2013, 787). Moving on now to a more diachronic perspective, during the Middle Bronze Age I (ca. 2000-1800 BC), the political landscapes of central Anatolia and the Khabur Triangle were divided into hundreds of city-states and tribal communities. The situation partially changed in the MBA II (ca. 1800-1600 BC), when large and centralized territorial states imposed their authority upon numerous and weaker existing political entities. In this period, the Khabur Triangle was part of Šamši-Adad I's kingdom (ca.1808-1776 BC) and subsequently of Zimri-Lim's kingdom (ca.1780$1758 \mathrm{BC}$ ), two territorial states which exerted their authority over most of Upper Mesopotamia (Villard 1995; Charpin and Ziegler 2003; Fleming 2004, 26-103; Van de Mieroop 2007, 107). In particular, the Khabur Triangle played a prominent role in the international political scenario of the early 18th century BC as the seat of the capital of Šamši-Adad I's kingdom (ca. 1808-1776 BC) at Šubat- Enlil/Šehna (Tell Leilan). In the second half of the 18th century, Anitta (?-1725 BC) was able to impose his power over the southern half of central Anatolia, and the texts suggest he took the title of Great King (Hamblin 2006, 293-294; Barjamovic et al., 2012, 50). Nevertheless, the city-states remained the more stable and longest-lasting political unit, while the larger regional kingdoms were often politically fragile and could last only one generation or a single dynasty (Barjamovic 2013, 123; Garfinkle 2013). 


\section{Conclusions}

The observed rank-size distributions have demonstrated the importance of a multi-scalar modeling approach to have a better and fully understanding of settlement hierarchies. In particular, zooming in and out in a given study area allows researchers to assess variations in spatial patterning and detect certain settlement structures only at a specific geographical level. In practical terms, this approach has shown that in the MBA balkanized landscapes of central Anatolia and the Khabur Triangle, a well-integrated political system is discernible at the spatial level of modestly-sized citystates. A first inference of the political dynamics occurring in central Anatolia and the Khabur Triangle has been made possible through the textual evidence from Tell Leilan (Eidem 2000 and 2008; Ristvet 2008, 586-592) and Kültepe (Veenhof and Eidem 2008; Barjamovic et al. 2012, 3551). In this paper, the picture provided by the historians is, therefore, supplemented with quantitative analyses of archaeological settlement data investigating past human landscapes both at a global and local scale.

Apart from the case of very few sites that, to some degree, have yielded a quite clear chronological sequence, most sites have offered only a coarser temporal resolution. Therefore, a diachronic development of political MBA cannot be offered in detail, but only roughly treating the MBA time span as a whole. A further improvement of this research could involve aoristic models to address the temporal uncertainty in the archaeological dataset (see Crema et al. 2010; Crema 2012; Orton 2017). Finally, a future research endeavour should apply a multi-scalar approach to a longer-term chronological framework in order to assess how settlement hierarchies change over the longue durée in periods of political fragmentation and unification.

\section{Acknowledgments}

This paper benefited from the comments by Mark Altaweel and Andrew Bevan who provided thoughtful comments, feedbacks, and suggestions. I also thank Enrico Crema for providing statistical advises and the code for calculating the $A$-coefficient, which is written in $\mathrm{R}$ statistical computing language. I would also thank Eva Jobbova, Francesco Iacono and Toby Wilkinson for conversations on city-states related themes. 


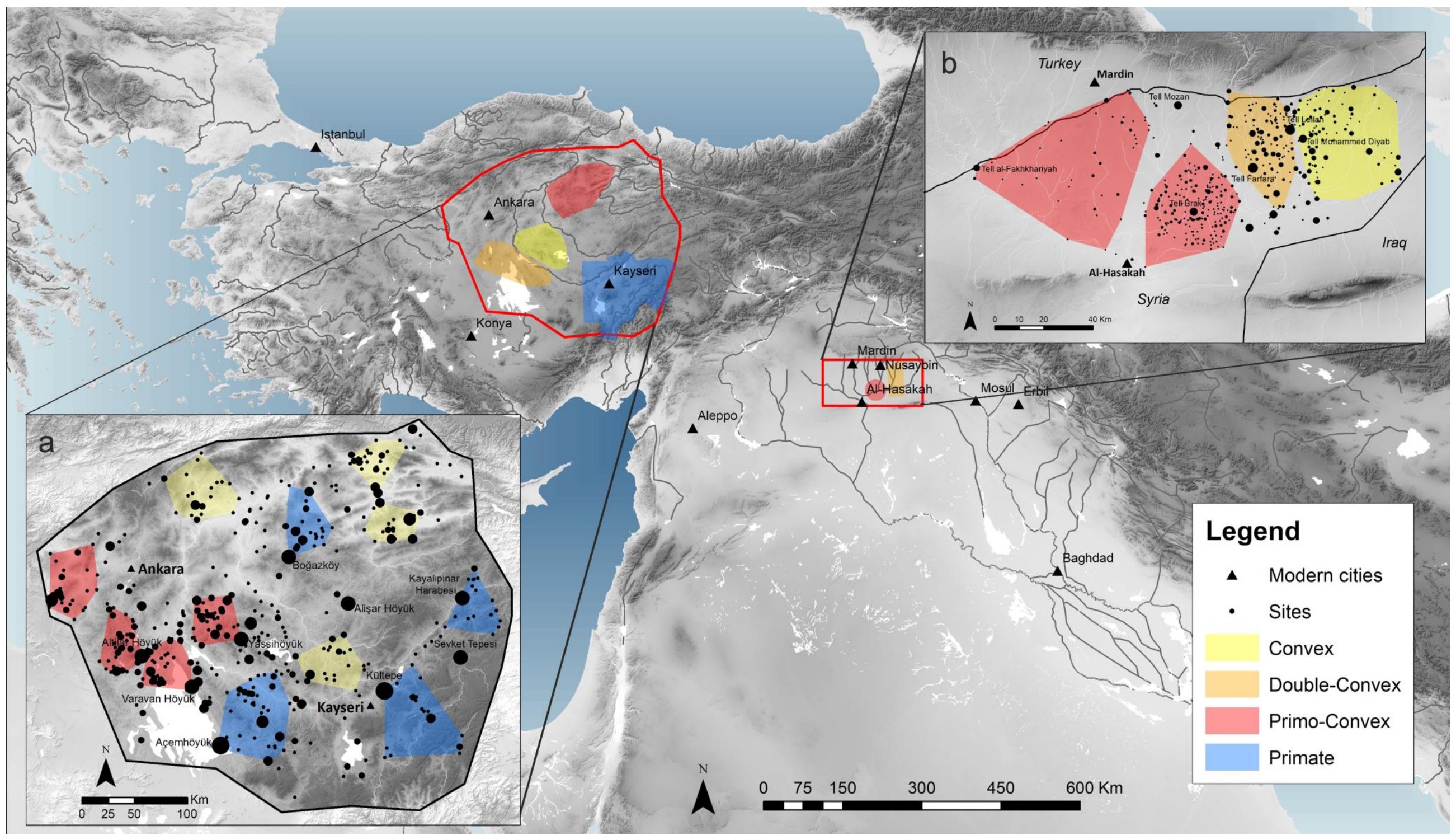

Figure 12. Spatial distribution of rank-size patterns in central Anatolia (a) and the Khabur Triangle (b). 


\section{References}

Abay, E., 2011. Preliminary report on the survey project of Çivril, Baklan and Çal plains in the Upper Meander Basin, southwest Anatolia. Ancient Near Eastern Studies 48, 1-87.

Adams, R., 1981. Heartland of Cities: Surveys of Ancient Settlement and Land Use on the Central Floodplain of the Euphrates. Chicago: University of Chicago Press.

Ades, A.F., and Glaeser, E.L., 1995. Trade and circuses: explaining urban giants. The Quarterly Journal of Economics 110 (1), 195-227.

Altaweel, M., Palmisano, A. and Hritz, C., 2015. Evaluating settlement structures in the ancient Near East using spatial interaction entropy maximization. Structure and Dynamics: eJournal of Anthropological and Related Sciences 8(1).

Algaze, G., 1989. A New Frontier: First Results of the Tigris-Euphrates Archaeological Reconnaissance Project, 1988. Journal of Near Eastern Studies 48 (4), 241-281.

Auerbach, F. 1913. Das Gesetz der Bevolkerungskontration. Petermanns Mitteilungen 1913, 74.

Ball, W., 2003. Ancient settlement in the Zammar Region: excavations by the British Archaeological Expedition to Iraq in the Saddam Dam Salvage Project, 1985-86. BAR International Series 1096. Oxford: Archaeopress.

Banning, E. B., 1996. Highlands and lowlands: Problems and survey frameworks for rural archaeology in the Near East. Bulletin of the American Schools of Oriental Research 301, 25-45.

Banning, E.B., 2002. Archaeological survey. Manuals in Archaeological Method, Theory, and Technique. New York: Kluwer Academic/Plenum Publishers.

Barjamovic, G., 2011. A Historical Geography of Anatolia in the Old Assyrian Colony Period. Copenhagen: Carsten Niebuhr Institute Publications.

Barjamovic, G., 2013. Mesopotamian Empires. In: Bang, P. F., and Scheidel, W., (eds.), The Oxford Handbook of the State in the Ancient Near East and Mediterranean. Oxford: Oxford University Press: 120160.

Barjamovic, G., Hertel, T., and Larsen, M. G., 2012. Ups and Down at Kanesh. Chronology, Histori and Society in the Old Assyrian Period. Leiden: Nederlands Instituut Voor Het Nabije Oosten.

Baxter, M. J., 2009. Archaeological data analysis and fuzzy clustering. Archaeometry 51, 1035-1054.

Baxter, M.J., 2015. Spatial k-Means Clustering in Archaeology-Variations on a Theme. Working Paper.

Berry, B. J. L. (1973). The Human Consequences of Urbanization. New York: St Martin's.

Berry, B.J. and Okulicz-Kozaryn, A., 2012. The city size distribution debate: Resolution for US urban regions and megalopolitan areas. Cities 29, 17-23.

Bird, J. H., 1989. The Changing Worlds of Geography: A Critical Guide to Concepts and Methods. Oxford: Oxford University Press.

Blank A., and Solomon S., 2000. Power laws in cities population, financial markets and internet sites (scaling in systems with a variable number of components). Physica A 287, 279-288. 
Blankholm, H. P., 1991. Intrasite Spatial Analysis in Theory and Practice. Aarhus: Aarhus University Press.

Blanton, R. E., 1976. The role of symbiosis in adaptation and sociocultural change. In: E.R. Wolf (Ed.), The Valley of Mexico: Studies in Prehispanic Ecology and Society. Albuquerque: University of New Mexico Press, 181-201.

Boyer, P., Roberts, N., and Baird, D., 2006. Holocene environment and settlement on the Çarsamba alluvial fan, south-central Turkey: Integrating geoarchaeology and archaeological field survey. Geoarchaeology 21 (7), 675 - 98.

Brakman S., Garretsen H., Marrewijk C. van, and Berg M. van der, 1999. The return of Zipf: towards a further understanding of the rank-size distribution, Journal of Regional Science 39(1), 183-213.

Carneiro, R. L., 1970. A theory of the origin of the state: Traditional theories of state origins are considered and rejected in favor of a new ecological hypothesis. Sciencel69 (3947), 733-738.

Carneiro, R. L., 1981. The Chiefdom as Precursor of the State. In: Jones, G. and Kautz, R. (eds.), The Transition to Statehood in the New World. Cambridge: Cambridge University Press, 39-79.

Charlton, T. H., and Nichols, D., 1997. The City-State Concept. Development and Applications. In:

Charlton, T. H., and Nichols, D. (eds.), The Archaeology of City-States. Washington: Smithsonian Institution Press, 1-14.

Charpin, D., 1987. Shubat Enlil et le pays d'Apum. M.A.R.I. 5, 129-141.

Charpin, D. and, Ziegler, N., 2003. Florilegium marianum. 5, Mari et le Proche-Orient à l'époque amorrite : essai d'histoire politique. Paris: Société pour l'étude du Proche-Orient ancien.

Chatters J. C., and Prentiss, W. C., 2005. A Darwinian macro-evolutionary perspective on the development of hunter-gatherer systems in northwestern North America. World Archaeology 37, 46-65.

Claessen, H. J. M., and Skalník, P., 1978. The early state: Theories and hypotheses. In: Claessen, H. J. M., and Skalník, P. (eds.), The early state. The Hague: Walter de Gruyter

Clauset, A., Shalizi, C.R. and Newman, M.E., 2009. Power-law distributions in empirical data. SIAM review 51(4), 661-703.

Colantoni, C., 2012. Touching the void. The Post-Akkadian period viewed from Tell Brak. In: Weiss, H. (ed.), Seven Generations Since the Fall of Akkad. Studia Chaburensia, vol. 3. Wiesbaden: Harrasowitz, 4564.

Crema, E.R., Bevan, A. and Lake, M.W., 2010. A probabilistic framework for assessing spatio-temporal point patterns in the archaeological record. Journal of Archaeological Science, 37(5), 1118-1130.

Crema, E.R., 2012. Modelling temporal uncertainty in archaeological analysis. Journal of Archaeological Method and Theory, 19(3), 440-461.

Crema, E. R., 2013. Cycles of change in Jomon settlement: a case study from eastern Tokyo Bay, Antiquity 87, 1169-1181.

Crema, E.R., 2014. A simulation model of fission-fusion dynamics and long-term settlement change. Journal of Archaeological Method and Theory 21(2), 385-404. 
Cristelli, M., Batty, M. and Pietronero, L., 2012. There is more than a power law in Zipf. Scientific reports 2, 812.

Crumley, C. L., 1976. Towards a locational definition of state systems of settlement. American Anthropologist 78, 59-73.

Crumley, C.L., 1979. Three locational models: an epistemological assessment for anthropology and archaeology. In: Schiffer, M.B. (Ed.), Advances in Archaeological Method and Theory, vol. 2. New York: Academic Press, 141-173.

Crumley, C.L., 1995. Heterarchy and the analysis of complex societies. In: Ehrenreich, R.M., Crumley, C.L., and Levy, J.E., (eds.), Heterarchy and the Analysis of Complex Societies. Archaeological Papers of the AmericanAnthropological Association 6: 1-5. Arlington, Virginia: American Anthropological Association.

Daly, P., and Lock, G., 2004. Time, Space and Archaeological Landscapes: Establishing Connections in the First Millennium BC. In: M.F. Goodchild and D.G. Janelle (Eds.), Spatially Integrated Social Science. Oxford: Oxford University Press, 349-365.

De Cáceres, M., 2016. Package 'vegclust'.

De Cáceres, M. and Wiser, S.K., 2016. How to use the vegclust package (ver. 1.6. 5).

Di Cosmo, N., 2000. Ancient City-States of the Tarim Basin. In: Hansen, M. H. (ed.), A Comparative Study of Thirthy City-State Cultures. Copenhagen: Special-Trykkeriet Viborg, 393-407.

Dixon, B., Gosser, D, and Williams, S. S., 2008. Traditional Hawaiian men's houses and their socio-political context in Lualualei, Leeward West O'ahu, Hawai'i. Journal of the Polynesian Society 117, 267-295.

Dönmez, S. 1999. Sinop-Samsun-Amasya illeri yuzey arastırmas1 1997. Arastırma Sonuçları Toplantısı 16(2): 513-36.

Dönmez, S. 2000. Sinop-Samsun-Amasya illeri yüzey ara\$tırması 1998. Arastırma Sonuçları Toplantısı 17(2), 229-244.

Dönmez, S. 2002. The 2nd millennium B.C. settlements in Samsun and Amasya Provinces, central Black Sea region, Turkey. Ancient East and West 1(2), 243-293.

Drennan, R. D., and Peterson, C. E., 2004. Comparing archaeological settlement systems with rank-size graphs: a measure of shape and statistical confidence. Journal of Archaeological Science 31, 533-549.

Drennan, R.D., and Peterson, C.E., 2008. Centralized communities, population, and social complexity after sedentarization. In: Bocquet-Appel, J.-P., Bar-Yosef, O. (Eds.), The Neolithic Demographic Transition and Its Consequences. New York: Springer, 359-386.

Duffy, P.R., 2015. Site size hierarchy in middle-range societies. Journal of Anthropological Archaeology, 37, 85-99.

Durand, J. M., 2004. Peuplement et sociétés à l'époque amorrite les clans bensim'alites. In: Nicolle, C. (ed.), Nomades et sedentaires dans le Proche-Orient ancien : compte rendu de la XLVIe Rencontre assyriologique internationale, Paris, 10-13 juillet 2000. Paris: Éditions recherche sur les civilisations.

Dziewoński, K., 1972, December. General theory of rank-size distributions in regional settlement systems: reappraisal and reformulation of the rank-size rule. In Papers of the Regional Science Association 29, No. 1, 73-86. 
Eidem, J., 2000. Northern Jazira in the 18th century BC. Aspects of geo-political patterns. In: O. Rouault and M. Wäfler (eds.), La Djéziré et l'Euphrate syriens de la protohistoire à la fin du Ile millénaire av. J. -C.: tendances dans l'interprétation historique des données nouvelles. Subartu, 7. Turnhout: Brepols, 255-64.

Eidem, J., 2008. The evidence from Tell Leilan. In: Dercksen, J. G. (ed.), Anatolia and the Jazira during the Old Assyrian Period. Leiden: Nederlands Instituut Voor Het Nabije Oosten, 31-41.

Eidem, J., 2010. The Royal Archives from Tell Leilan. Old Babylonian Letters and Treaties from the Eastern Lower Town Palace. New Haven and London: Yale University Press.

Eidem, J., and Warburton, D., 1996. In the Land of Nagar: A Survey around Tell Brak. Iraq 58, 51-64.

Emberling, G., and N. Yoffee, 1999. Thinking About Ethnicity in Mesopotamian Archaeology and History. In: Hans Nissen, H. Kuhne, R. Bernbeck, and K. Bartl (Eds.), Fluchtpunkt Uruk. Archäologische Einheit aus Methodischer Vielfalt Schriften für Hans Nissen. Rahden: Marie Leidorf, 272-281.

Engin, A., 2009. Sivas ili 2007 yılı yuzey arastırması. Arastırma Sonuçları Toplantısı 26(2), 73-94.

Falconer, S. E. and Savage, S. H., 1995. Heartlands and Hinterlands: Alternative Trajectories of Early Urbanization in Mesopotamia and the Southern Levant. American Antiquity, 60, 37-58.

Fall, P.L., Lines, L. and Falconer, S.E., 1998. Seeds of civilization: Bronze Age rural economy and ecology in the southern Levant. Annals of the Association of American Geographers 88(1), 107-125.

Fleming, D.A. 2004. Democracy's ancient ancestors: Mari and early collective governance. Cambridge: Cambridge University Press.

Forge, A., 1972. Normative factors in the settlement size of Neolithic cultivators (New Guinea). In: Ucko, P.J., Tringham, R., Dimbleby, G.W. (Eds.), Man, Settlement and Urbanism. London: Duckworth, 363-381.

Fox, Richard G., 1977. Urban Anthropology: Cities in their Cultural Settings. Englewood Cliffs, NJ: Prentice-Hall.

Flannery, K.V., 1976. The village and its catchment area. In: Flannery, K.V. (Ed.), The Early Mesoamerican Village. New York: Academic Press, 91-95.

Garfinkle, S. J., 2013. Ancient Near Eastern City-States. In: Bang, P. F., and Scheidel, W., (eds.), The Oxford Handbook of the State in the Ancient Near East and Mediterranean. Oxford: Oxford University Press, 94-119.

Glatz, C., Matthews, R., and Schachner, A., 2009. A Landscape of Conflict and Control: Paphlagonia during the Second Millennium BC. In: Matthews, R. and Glatz, C. (eds.), At empires' edge: project Paphlagonia. Regional survey in North-Central Turkey. London: British Institute at Ankara, 107-147.

Goodchild, M. F., and Quattrochi, D. A., 1996. Introduction: Scale, Multiscaling, Remote Sensing, and GIS. In: D. A. Quattrochi and M. F. Goodchild (Eds.), Scale in Remote Sensing and GIS. Boca Raton, FL: Lewis Publishers, 1-11.

Gülçür, S. 1995. Some Unknown Aspects of Western Cappadocia: Results of the 1993 Survey, in Çambel (ed.), Readings in prehistory: studies presented to Halet Çambel. Istanbul: Graphis, 149-73.

Habu, J. 2001. Subsistence-settlement systems and intersite variability in the Moroiso phase of the Early Jomon period of Japan. Ann Arbor (MI): International Monographs in Prehistory. 
Hamblin, W. G., 2006. Warfare in the Ancient Near East to 1600 BC. London and New York: Routledge.

Hansen, M. H., 2000. The concepts of City-State and City-State Culture. In: Hansen, M. H., (ed.), A Comparative Study of Thirty City-State Cultures. Copenhagen: Special-Trykkeriet Viborg.

Hansen, M.H., 2002. A comparative study of Six City-State Cultures. Copenhagen: Special-Trykkeriet Viborg.

Harris, T.M., 2006. Scale as artifact: GIS, ecological fallacy, and archaeological analysis. In Lock, G. and Molyneaux, B.L. (Eds.), Confronting scale in archaeology. New York: Springer, 39-53.

Hinsley, F. H., 1986. Sovereignity. Cambridge: Cambridge University Press.

Hodder, I., and Orton, C. 1976. Spatial Analysis in Archaeology. Cambridge: Cambridge University Press.

Jiang, B., Yin, J. and Liu, Q., 2015. Zipf's law for all the natural cities around the world. International Journal of Geographical Information Science, 29(3), 498-522.

Joannès, F., 1996. Routes et voies de communication dans les archives de Mari. In: J. M. Durand (ed.), Mari, Ébla et les Hourrites. Dix ans de travaux. Première partie. Actes du colloque international (Paris, mai 1993)(Amurru 1). Paris: Éditions Recherche sur les Civilisations, 323-361.

Johnson, G. A., 1972. A test of the utility of central place theory in archaeology. In: P. Ucko, R. Tringham and G. W. Dimbleby, (Eds.), Man, Settlement, and Urbanism. Cambridge, MA: Shenkman Press, 769-785.

Johnson, G.A, 1977. Aspects of regional analysis in archaeology. Annual Review of Anthropology 6, 479508.

Johnson, G. A., 1980. Rank-size convexity and system integration: a view from archaeology Economic Geography 56, 234-247.

Jones, R. 2010. The village and the butterfly: nucleation out of chaos and complexity. Landscapes 11: $25-46$.

Kantner, J., Kintigh, K.W., 2006. The Chaco world. In: Lekson, S.H. (Ed.), The Archaeology of Chaco Canyon: an Eleventh-century Pueblo Regional Center. Santa Fe, NM: School of American Research Press, 153-188.

Kaufman, L. and Rousseeuw, P. J., 1990. Finding Groups in Data. An Introduction to Cluster Analysis. New York: John Wiley \& Sons, Inc.

Kealhofer, L. 2005. Settlement and land use: the Gordion regional survey. In: Kealhofer, L. (ed.), The Archaeology of Midas and the Phrygians: Recent Work at Gordion, 137-148.

Kelly, R.L., 1992. Mobility/sedentism: concepts, archaeological measures, and effects. Annual Review of Anthropology 21(1), 43-66.

Kintigh, K. W. and Ammerman, A. J., 1982. Heuristic Approaches to Spatial Analysis in Archaeology. American Antiquity 47, 31-63.

Kintigh, K. W., 1990. Intrasite Spatial Analysis: A Commentary on Major Methods. In: A. Voorrips (ed.), Mathematics and Information Science in Archaeology: A Flexible Framework. Bonn: Studies in Modern Archaeology, Vol. 3, 165-200. 
Koetje, T. A., 1987. Spatial Patterns in Magdalenian Open Air Sites from the Isle Valley, Southwestern France. BAR International Series 346. Oxford: Archaeopress.

Kohler, T.A. (Ed.), 2004. Archaeology of Bandelier National Monument: Village Formation on the Pajarito Plateau, New Mexico. Albuquerque: University of New Mexico Press.

Kolinski, R., 2014. 20th Century BC in the Khabur Triangle Region and the Advent of the Old Assyrian Trade with Anatolia. In: Bonatz, D. (ed.), Archaeology of Political Spaces, The Upper Mesopotamian Piedmont in the 2nd Millennium BCE. Berlin: Topoi - Berliner Studien in Antike Welt bd.12, 11-34.

Kowalewski, S., 1982. The evolution of primate regional systems. Comparative Urban Research 9, 60-78.

Kowalewski, S. A., 1990. The Evolution of Complexity in the Valley of Oaxaca. Annual Review of Anthropology 19, 39-58.

Krugman, P., 1991a. Increasing returns and economic geography. Journal of Political Economy 99, 483-499.

Krugman, P., 1991b. Geography and trade. Cambridge, MA: MIT Press.

Ladefoged, T. N. and Pearson, R., 2000. Fortified Castles on Okinawa Island During the Gusuku Period, AD 1200-1600. Antiquity $74,404-412$.

Lawrence, D., Philip, G., Wilkinson, K., Buylaert, J.P., Murray, A.S., Thompson, W. and Wilkinson, T.J., 2015. Regional power and local ecologies: Accumulated population trends and human impacts in the northern Fertile Crescent. Quaternary International.

Lemke, A. K., 2013. Cutmark systematics: Analyzing morphometrics and spatial patterning at Palangana. Journal of Anthropological Archaeology 32, 16-27.

Lock, G. and Molyneaux, B.L., 2006. Introduction: Confronting Scale. In: Lock, G. and Molyneaux, B.L. (Eds.), Confronting scale in archaeology. New York: Springer, 1-11.

Lyonnet, B., 1996. La prospection archéologique de la partie occidentale du Haut-Khabur (Syrie du N.E.): méthodes, résultats et questions autour de l'occupation aux IIIe et IIemill'enaires av. n.é. In: J.-M. Durand (ed.), Amurru: Mari, Ebla et les Hourrites, dix ans de travaux, I ere partie (Actes du colloque international, Paris, Mai 1993). Paris: Recherche sur les Civilisations, 363-76.

Lyonnet, B., 1997. Questions sur l'origine des porteurs de pots en Haute-Mésopotamie, duVIe au millieu de IIe millénaire. In: D. Charpin and J.-M. Durand. (eds.), FlorilegiumMarianum 3: Recueil d'études à la mémoire de Mari-Thérèse Barrelet. Mémoires de NABU 4. Paris: SEPOA, 133-144.

Lyonnet, B., 2000. Haut-Khabur Occidental. Beyrouth: Institut Francais du Proche Orient.

Marcus, J., 1998. The peaks and valleys of ancient states: An extension of the dynamic model. In: Feinman, M., and Marcus, J., (eds.), Archaic States. Santa Fe, NM: School of American Research Press.

Marzano, A., 2011. Rank-size analysis and the Roman cities of the Iberian Peninsula and Britain: some considerations. In: Bowman, A. and Wilson, A. (eds.), Settlement, urbanization, and population. Oxford: Oxford University Press, 196-228.

Mathieu, J.R., and Scott, R.E., 2004. Introduction: Exploring the Role of Analytical Scale in Archaeological Interpretation. In: J.R. Mathieu and R.E. Scott (Eds.), Exploring the Role of Analytical Scale in Archaeological Interpretation. Oxford: BAR International Series 1261, 1-9. 
Peeples, M. A., 2011. R Script for K-Means Cluster Analysis. [online]. Available:

http://www.mattpeeples.net/kmeans.html. ( January 14, 2017 )

Matthews, R. and Glatz, C., 2009. At empires' edge: project Paphlagonia. Regional survey in North-Central Turkey. London: British Institute at Ankara.

Meijer, D. J. W., 1986. A Survey in Northeastern Syria. Leiden: Nederlands Historisch-Archaeologisch Institute Instanbul.

Menze, B.H. and Ur, J.A., 2012a. Mapping patterns of long-term settlement in Northern Mesopotamia at a large scale. Proceedings of the National Academy of Sciences 109(14), E778-E787.

Bjoern Menze; Jason Ur, 2012b. Replication data for: Patterns of long-term settlement in the Upper Khabur Basin, northeastern Syria. hdl:1902.1/17731, Harvard Dataverse, V2

Menze, B. H., and, Ur, J. A., 2013. Mapping Anthrosols in Multi-Spectral Images using a Multi-Temporal Classification Strategy: An Approach to Settlement Survey at a Large Scale in the Upper Khabur Basin, Syria. In: D. C. Comer, and M. J. Harrower (eds.), Mapping Archaeological Landscapes from Space. New York: Springer, 209-218.

Menze B. H., Muehl S., Sherratt, A. G., 2007. Virtual survey on north Mesopotamian tell sites by means of satellite remote sensing. In: B. Ooghe, G. Verhoeven (eds.), Broadening horizons: Multidisciplinary Approaches to Landscape Study. Newcastle: Cambridge Scholars Publishing, 5-29.

McAndrews, T.L., Albarracin-Jordan, J. and Bermann, M., 1997. Regional settlement patterns in the Tiwanaku Valley of Bolivia. Journal of Field Archaeology 24(1), 67-83.

Michel, C., 2003. Old Assyrian Bibliography of Cuneiform Texts, Bullae, Seals and the Results of the Excavations at Assur, Kültepe/Kanis, Acemhöyük, Alishar and Bogazköy. Old Assyrian Archives Studies 1. Leiden: Publications de l'Institut historique-archéologique néerlandais de Istamboul 97.

Michel, C., 2006. Old Assyrian Bibliography 1 (February 2003- July 2006). Archiv für Orientforschung 51, 436-449.

Michel, C., 2011. Old Assyrian Bibliography 2 (August 2006-April 2009). Archiv für Orientforschung 52, 416-437.

Oguchi, H., 2006. The date of the beginning of Khabur Ware Period 3. Al-Rafidan 27, 45-58.

Ökse, A.T. 1994. Sivas ili 1992 yuzey arastırması. Arastırma Sonuçları Toplantısı 11, 243-258.

Ökse, A.T. 1995. Sivas ili 1993 yuzey arastırması. Arastırma Sonuçları Toplantısı 12, 317-329.

Ökse, A.T. 1996. Sivas ili 1994 yuzey arastırması. Arastırma Sonuçları Toplantısı 13(1), 205-228.

Ökse, A.T. 1997. Sivas ili 1995 yuzey arastırması. Arastırma Sonuçları Toplantısı 14(2), 375-400.

Ökse, A.T. 1999. Sivas ili 1997 yuzey arastırması. Arastırma Sonuçları Toplantısı 16(1), 467-490.

Ökse, A.T. 2000. Sivas ili 1998 yuzey arastırması. Arastırma Sonuçları Toplantısı 17(2), 11-24.

Ökse, A.T. 2001. Sivas ili 1999 yuzey arastırması. Arastırma Sonuçları Toplantısı 18(2), 89-100.

Omura, S., 1992. 1990 yılı orta Anadolu'da yurutulen yuzey arastırmaları. Arastırma Sonuçları Toplantısı 9 , 541-560. 
Omura, S., 1993. 1991 yili iç Anadolu'da yürütülen yüzey arastirmalari. Arastırma Sonuçları Toplantısı 10, 365-386.

Omura, S.,1994. 1992 yili iç Anadolu'da yürütülen yüzey arastirmalari. Arastırma Sonuçları Toplantısı 11, 311-336.

Omura, S. 1995. 1993 yili iç Anadolu'da yürütülen yüzey arastirmalari. Arastırma S onuçları Toplantısı 12, 215-244.

Omura, S., 1996a. 1994 yili iç Anadolu'da yürütülen yüzey arastirmalari. Arastırma Sonuçları Toplantısı 13(2), 243-272. 276

Omura, S., 1996b. A preliminary Report of the General Survey in Central Anatolia (1994), Bulletin of the Middle Eastern Culture Center in Japan 9, 135-192.

Omura, S., 1997. 1995 yili iç Anadolu'da yürütülen yüzey arastirmalari, Arastırma Sonuçları Toplantısı 14(2), 283-302.

Omura, S., 1998. 1996 yili iç Anadolu'da yürütülen yüzey arastirmalari, Arastırma Sonuçları Toplantısı 15(2), 41-50.

Omura, S., 2000. Preliminary report of the general survey in Central Anatolia (1999), Anatolian Archaeological Studies 9. Kaman-Kalehöyük 9, 37-96.

Omura, S., 2001a. 1999 yili iç Anadolu'da yürütülen yüzey arastirmalari, Arastırma Sonuçları Toplantısı 18(2), 83-88.

Omura, S., 2001b. Preliminary report of the general survey in Central Anatolia (2000), Anatolian Archaeological Studies 10. Kaman-Kalehöyük 10, 37-86.

Omura, S., 2002. Preliminary report of the general survey in Central Anatolia (2001), Anatolian Archaeological Studies 11. Kaman-Kalehöyük 11, 45-112.

Omura, S., 2003. Preliminary report of the general survey in Central Anatolia (2002), Anatolian Archaeological Studies 11. Kaman-Kalehöyük 12, 37-88.

Omura, S., 2006. Preliminary report of the general survey in Central Anatolia (2005), Anatolian Archaeological Studies 15. Kaman-Kalehöyük 15, 63-102.

Omura, S., 2007a. Preliminary report of the general survey in Central Anatolia (2006), Anatolian Archaeological Studies 16. Kaman-Kalehöyük 16, 45-84.

Omura, S., 2007b. 2003-2006 yillarinda iç Anadolu'da yapilmiş olan yüzey arastirmalari, Arastırma Sonuçları Toplantısı 25(2), 213-224.

Omura, S., 2008. Preliminary report of the general survey in Central Anatolia (2007), Anatolian Archaeological Studies 17. Kaman-Kalehöyük 17, 45-92.

Orton, D., Morris, J. and Pipe, A., 2017. Catch Per Unit Research Effort: Sampling Intensity, Chronological Uncertainty, and the Onset of Marine Fish Consumption in Historic London. Open Quaternary, 3(1).

Osborne, J. F., 2013. Sovereignty and Territoriality in the City-State: A Case-Study from the Amuq Valley, Turkey. Journal of Anthropological Archaeology 32, 774-790. 
Özdogan, M. The Lower Euphrates Basin 1977 Survey. Ankara: East Technical University Lower Euphrates Publications.

Özsait, M., 1991. 1989 yılı Göynücek çevresi tarihöncesi araştırmaları. Arastırma Sonuçları Toplantısı 8, 4554.

Özsait, M., 1998. 1995 ve 1996 Yillarinda Amasya - Merzifon ve Gümüshaciköy yüzey arastirmalari. Arastırma Sonuçları Toplantısı 15(2), 143-161.

Özsait, M., 1999. 1997. Yılı Tokat ve Çevresi yuzey arastırmaları. Arastırma Sonuçları Toplantısı 16(2), 89107.

Özsait, M., 2000. 1997 ve 1998 Yılı Tokat-Zile ve çevresi yüzey arastırmaları. Arastırma Sonuçları Toplantıst 17(2), 73-88.

Özsait, M. 2002. 1999-2000 Yılı Amasya-Merzifon ve Ordu-Kumru yüzey aradtırması. Aradtırma Sonuçları Toplantısı 19(2), 191-216.

Özsait, M. 2003. 2001 Yı1ı Samsun ve Amasya yüzey arastırmaları. Arastırma Sonuçları Toplantısı 20(2), 127-150.

Özsait, M. 2004. 2002 Yı1ı Samsun-Amasya yüzey arastırmalarının ilk sonuçları. Arastırma Sonuçları Toplantısı 21(2), 273-284.

Özsait, M. 2005. 2003 Y1lı Amasya, Samsun ve Ordu illeri yüzey arastırmaları. Arastırma Sonuçları Toplantısı 22(2), 263-274.

Özsait, M. 2006. 2004 Y1lı Samsun ve Amasya illeri yüzey arastırmaları. Arastırma Sonuçları Toplantısı 23(2), 249-258.

Özsait, M. 2007. 2005 yılı Tokat ili, Zile ve Turhal ilçeleri yüzey araştırması. Arastırma Sonuçları Toplantısı 24 (2), 451-462.

Özsait, M. 2009. Yılı Amasya-Suluova yüzey arastırmaları. Arastırma Sonuçları Toplantısı 26(2), 373-390.

Özsait, M. and Özsait, N. 2001. Les sites archéologiques du IIe millénaire avant J.-C. à Tokat. In: Wilhelm, G., (ed.). Akten des IV. Internationalen Kongresses für Hethitologie. Würzburg 4.-8. Oktober 1999,

Palmisano, A., 2014. Geo-Politics and Trade in Central Anatolia in the Middle Bronze Age. In: Bielinski, P., Gawlikowski, M., Kolinski, R., Lawecka, D., and Soltysiak, A. (eds.), Proceedings of the 8th International Congress on the Archaeology of the Ancient Near East, 30 April - 4 May 2012. Wiesbaden: HarrassowitzVerlag, 51-63.

Palmisano, A., 2015. Geopolitical Patterns and Connectivity in the Upper Khabur Valley in the Middle Bronze Age. In: Archi, A. (ed.), Tradition and Innovation in the Ancient Near East. Proceedings of the 57th Rencontre Assyriologique Internationale at Rome, 4-8 July 2011. Winona lake: Eisenbrauns.

Palmisano, A., and Altaweel, M., 2015a. Landscapes of interaction and conflict in the Middle Bronze Age: From the open plain of the Khabur Triangle to the mountainous inland of Central Anatolia. Journal of Archaeological Science: Reports 3, 216-236.

Palmisano, A., and Altaweel, M, 2015b. Simulating Past Human Landscapes: Models of Settlement Hierarchy in Central Anatolia during the Old Assyrian Colony Period. In: F. Kulakoğlu, and C. Michel (eds.), Proceedings of the 1st Kültepe International Meeting. Kültepe, September 19-23, 2013. Studies Dedicated to Kutlu Emre. Subartu 35.Turnhout: Brepols, 131-146. 
Paynter, R.W., 1982. Models of Spatial Inequality: Settlement Patternsin Historical Archaeology. New York: Academic Press.

Pearson, C. E., 1980. Rank-size distributions and the analysis of prehistoric settlement systems. Journal of Anthropological Research 36, 453-462.

Pearson, M.P., Pollard, J., Richards, C., Thomas, J., Tilley, C., Welham, K. and Albarella, U., 2006.

Materializing Stonehenge the Stonehenge riverside project and new discoveries. Journal of Material Culture, $11(1-2), 227-261$.

Peterson, C.E. and Drennan, R.D., 2011. Patterned variation in regional trajectories of community growth. In: M. Smith (ed.), The comparative archaeology of complex societies. Cambridge: Cambridge University Press, 88-137.

Plog, S., Plog, F., and Wait, W., 1978. Decision Making in Modern Surveys. In: M. B. Schiffer (ed.), Advances in Archaeological Method and Theory. New York: Academic Press, 384-421.

Pollock, S., 2001. The Uruk Period in Southern Mesopotamia. In: M. Rothman (Ed.), Uruk Mesopotamia and Its Neighbors: Cross-Cultural Interactions in the Era of State Formation. Santa Fe: School of American Research Press, 181-231.

Price, T.D., Brown, J.A., 1985. Prehistoric Hunter-Gatherers: The Emergence of Cultural Complexity. Orlando: Academic Press.

Pumain, D. and Moriconi-Ebrard, F., 1997. City size distributions and metropolisation. Geojournal, 43(4), 307-314.

Renfrew, C., 1986. Introduction: peer polity interaction and socio-political change. In: Renfrew, C., and Cherry, J. F., (Eds.), Peer Polity Interaction and Socio-Political Change. Cambridge: Cambridge University Press, 1-18.

Renfrew, C., Todd, I., and Tringham, R., 1974. Beyond a subsistence economy: The evolution of social organization in prehistoric Europe. Bulletin of the American Schools of Oriental Research. Supplementary Studies 20, 69-95.

Renfrew, C., and Level, E.V., 1979. Exploring dominance: predicting polities from centers. In: Renfrew, C., Cooke, K.L. (Eds.), Transformations: Mathematical Approaches to Culture Change. New York, Academic Press, 145-167.

Ristvet, L., 2005. Settlement, economy, and society in the Tell Leilan Region, Syria, 3000-1000 BC. Unpublished dissertation, University of Cambridge.

Ristvet, L., 2008. Legal and archaeological territories of the second millennium BC in northern Mesopotamia. Antiquity 82, 585-99.

Ristvet, L., 2012. Resettling Apum: Tribalism and Tribal States in the Tell Leilan Region, Syria. In: A. Bianchi, N. Laneri, and S. Valentini (eds.), Looking North: The socioeconomic dynamics of the northern Mesopotamian and Anatolian regions during the late third and early second millennium $B C$. Wiesbaden: Harrasowitz, 37-50.

Ristvet, L., and Weiss, H., 2005. The Hābūr Region in the Late Third and Early Second Millennium B.C. In: W. Orthmann (ed.), The History and Archaeology of Syria. Vol. 1. Saabrucken: Saarbrucken Verlag. 
Ristvet, L., and Weiss, H., 2010. Introduction. In: Eidem, J., The Royal Archives from Tell Leilan. Old Babylonian Letters and Treaties from the Eastern Lower Town Palace. New Haven: Yale University Press, xi-li.

Ristvet, L., and Weiss, H., 2013. The Habur Region in the Old Babylonian Period. In: W. Orthmann, P. Matthiae, and M. al-Maqdissi (eds.), Archéologie et Histoire de la Syrie. Wiesbaden: Harrassowitz, 257-272.

Roberts, B.K., 1996. Landscapes of settlement: prehistory to the present. London: Routledge.

Roberts, M.B., and Parfitt, S.A., 1999. Boxgrove: A Middle Pleistocene Hominid Site at Eartham Quarry, Boxgrove, West Sussex. London: English Heritage.

Roth, M., 1997. Law collections from Mesopotamia and Asia Minor. Atlanta: Society of Biblical literature.

Rousseeuw, P. J., 1987. Silhouettes: A graphical aid to the interpretation and validation of cluster analysis. Journal of Computational and Applied Mathematics 20, 53-65.

Savage, S. H., 1997. Assessing Departures from Log-Normality in the Rank-Size Rule. Journal of Archaeological Science 24, 233-244.

Savage, S.H. and Falconer, S.E., 2003. Spatial and statistical inference of Late Bronze Age polities in the southern Levant. Bulletin of the American Schools of Oriental Research 330, 31-45.

Schiffer, M. B., A. P. Sullivan and T. C. Klinger, 1978. The Design of Archaeological Surveys. World Archaeology 10, 1-28.

Schoop, U. D., 2003. Pottery traditions of the later Hittite Empire: problems of definition. In: B. Fischer, H. Genz, É. Jean and K. Köroğlu (eds.), Identifying changes: The transition from Bronze to Iron Ages in Anatolia and its neighbouring regions. Proceedings of the international workshop Istanbul, November 8-9, 2002 Istanbul: Ege Yayınları, 167-178.

Schoop, U. D., 2006. Dating the Hittites with Statistics: Ten Pottery Assemblages from Boğazköy-Hattuša. In: D. P. Mielke, U. D. Schoop and J. Seeher (eds.), Strukturierung und Datierung in der hethitischen Archäologie. Voraussetzungen - Probleme - Neue Ansätze. Structuring and Dating in Hittite Archaeology. Requirements - Problems - New Approaches. Byzas 4. Istanbul: Ege Yayınları, 215-239.

Schoop, U. D., 2009. Indications of structural change in the Hittite pottery inventory at Boğazköy-Hattuša. In: F. Pecchioli Daddi, G. Torri and C. Corti (eds.), Central-North Anatolia in the Hittite Period. New Perspectives in Light of Recent Research. Acts of the International Conference held at the University of Florence (7-9 February 2007). Studia Asiana 5. Rome: Herder, 145-167.

Sipahi, T. and Yıldırım, T. 1999. 1997 Yılı Çorum bölgesi yüzey arastırmaları. Arastırma Sonuçları Toplantist 16(1), 433-450.

Sipahi, T. and Yıldırım, T. 2000. 1999 Yılı Çorum bölgesi yuzey arastırması. Arastırma Sonuçları Toplantısı $17(2), 31-40$.

Sipahi, T. and Yıldırım, T. 2004. 2002 Yılı Çorum ve Çankiri illeri yüzey arastırması. Arastırma Sonuçları Toplantısı 21(2), 305-313.

Sipahi, T. and Yıldırım, T. 2008. 2006 Yılı Çorum-Çankiri illeri yüzey arastırması. Arastırma Sonuçları Toplantısı 25(2), 277-294.

Smith, A., 2003. The political landscape. Berkley and Los Angeles: University of California Press. 
Smith, S. L., 2015. Late Chalcolithic to Early Bronze Age Settlement Patterns in the Greater Western Jazira: Trajectories of Sedentism in the Semi-Arid Syrian Steppe. Doctoral thesis, Durham University.

Strange, J., 2000. The Philistine City-States. In: Hansen, M. H., (ed.), A Comparative Study of Thirty CityState Cultures. Copenhagen: Special-Trykkeriet Viborg, 129-39.

Süel, A. 1990. 1988 Y1lı Çorum ili yüzey arastırmaları. Arastırma Sonuçları Toplantısı 7, 341-359.

Thuesen, I., 2000. The city-state in ancient western Syria. In: Hansen, M. H., (ed.), A Comparative Study of Thirty City-State Cultures. Copenhagen: Special-Trykkeriet Viborg, 55-66.

Trigger, B., 1972. Determinants of Urban Growth in Pre-Industrial Societies. In: Ucko, P. J., R. Tringham, R., and Dimbleby, G.W., (eds.), Man, Settlement and Urbanism. London: Duckworth and Co. Ltd, 575-599.

Trigger, B., 1993. Early Civilizations: Ancient Egypt in Context. Cairo: The American University in Cairo Press.

Turchin, P., Currie, T.E., Turner, E.A. and Gavrilets, S., 2013. War, space, and the evolution of Old World complex societies. Proceedings of the National Academy of Sciences, 110 (41), 6384-16389.

Ullah, I.I., 2011. A GIS method for assessing the zone of human-environmental impact around archaeological sites: a test case from the Late Neolithic of Wadi Ziqlâb, Jordan. Journal of Archaeological Science, 38(3), 623-632.

Ur, J. A., 2010a. Cycles of Civilization in Northern Mesopotamia, 4400-2000 BC. Journal of Archaeological Research 18, 387-431.

Ur, J. A., 2010b. Urbanism and Cultural Landscapes in Northeastern Syria: The Tell Hamoukar Survey, 1999-2001. Oriental Institute Publications 137. Chicago: University of Chicago Oriental Institute.

Ur, J. A., 2013. Patterns of Settlement in Sumer and Akkad. In: H. Crawford (Ed.), The Sumerian World. Oxford and New York: Routledge, 131-155.

Ur, J. A., Karsgaard, P., and Oates, J., 2007. Urban Development in the Ancient Near East. Science 317, 1188 .

Ur, J. A., and Wilkinson, T. J., 2008. Settlement and Economic Landscapes of Tell Beydar and its Hinterland. In: M. Lebeau and A. Suleiman (eds.), Beydar Studies I. Turnhout: Brepols, 305-327.

Ur, J., Karsgaard, P., and Oates, J., 2011. The spatial dimensions of early Mesopotamian urbanism: The Tell Brak suburban survey, 2003-2006. Iraq 73, 1-19.

Van De Mieroop, M., 2007. A History of the Ancient Near East. Oxford: Blackwell Publishing.

Vaquero, M., 1999. Intrasite spatial organization of lithic production in the Middle Palaeolithic:

The evidence of the Abric Ronan (Capellades, Spain). Antiquity 73 , 493-504.

Veenhof, K. R., and Eidem, J., 2008c. Mesopotamia, The Old Assyrian Period. Fribourg: Academic Press Fribourg.

Villard, P., 1995. Shamshi-Adad and Sons: The Rise and Fall of an Upper Mesopotamian Empire. In:

Sasson, J. (ed.), Civilizations of the Ancient Near East. New York: Simon \& Schuster MacMillan, 873-883.

Vita-Finzi, C., and Higgs, E.S., 1970. Prehistoric economy in the Mount Carmel area of Palestine: site catchment analysis. Proceedings of the prehistoric society 36, 1-37. 
Wattenmaker, P., 2009. States and Landscapes in Upper Mesopotamia. In: Falconer, S.E., and Redman, C. L., (eds.), Polities and Power. Archaeological Perspectives on the Landscape of Early States. Tucson: The University of Arizona Press.

Weber, M, 1978. Economy and Society: An outline of interpretative sociology. Berkley, CA: University of California Press.

Wilkinson, T., J., 2000. Regional approaches to Mesopotamian archaeology: The contribution of archaeological surveys. Journal of Archaeological Research 8(3), 219-67.

Wilkinson, T. J., 2002. Physical and Cultural Landscapes of the Hamoukar Area. Akkadica 123, 89-105.

Wilkinson, T. J., 2003. Archaeological Landscapes of the Near East. Tucson: University of Arizona Press.

Wilkinson, T. J. and Tucker, D. J., 1995. Settlement development in the North Jazira, Iraq: a study of the archaeological landscape. Iraq Archaeological Reports, 3. Warminster: Aris \& Phillips.

Wossink, A., 2009. Challenging Climate Change. Competition and cooperation among pastoralists and agriculturalists in northern Mesopotamia (c. 3000-1600 BC). Leiden: Sidestone Press.

Wright, H. T., 1978. Toward an Explanation of the Origin of the State. In: Cohen, R., and Service, E. R., (eds.), Origins of the State: The Anthropology of Political Evolution. Philadelphia: Institute for the Study of Human Issues, 49-68.

Wright, H. T., 1986. The Evolution of Civilizations. In: D. J. Meltzer, D. D. Fowler, and J. A. Sabloff (Eds.), American Archaeology Past and Future: A Celebration of the Society for American Archaeology, 1935-1985. Washington, DC: Smithsonian Institution, 323-65.

Wright, H. T., Rupley, E. S. A., Ur, J., Oates, J., and Ganem, E., 2006-2007. Preliminary Report on the 2002 and 2003 Seasons of the Tell Brak Sustaining Area Survey. Les Annales Archéologiques Arabes Syrienne 49-50, 7-21.

Yoffee, N., 2005. Myths of the Archaic State. Evolution of the Earliest Cities, States, and Civilizations. Cambridge: Cambridge University Press, 251-268.

Zipf, G. K., 1949. Human Behavior and the Principle of Least Effort. Cambridge, MA: Harvard University Press. 